\title{
O TRIUNFO DA VONTADE: ÉSQUILO NOS LIMITES DA IMAGINAÇÃO ACADÊMICA*
}

\author{
Rafael Faraco Benthien \\ Mestrando em História Social - FFLCH/USP
}

\section{Resumo}

Desde sua confecção, a tragédia esquiliana foi alvo de inúmeras hermenêuticas, nem sempre orientadas por um mesmo conjunto de problemas e conceitos. O presente artigo visa, de início, circunscrever as disposições gerais que marcaram o atual entendimento destes textos, para, em seguida, analisar os limites impostos por tais disposições às leituras acadêmicas de Ésquilo no século XX.

\section{Pallavras-Chave \\ Tragédia • Ésquilo $\bullet$ Kant $・$ Schiller $・$ Vontade \\ Abstract}

Ever since its creation, Aeschylean tragedy has been the object of innumerable hermeneutical studies, though not always guided by the same questions and concepts. This article aims to identify the general contours that have guided current understandings of these texts and to examine how these contours have limited scholarly readings of Aeschylus in the twentieth century.

\section{Keywords}

Tragedy $\bullet$ Aeschylus $\bullet$ Kant $\bullet$ Schiller $\bullet$ Will

\footnotetext{
*Deixo aqui registrada minha gratidão para com Francisco Murari Pires e Miguel Soares Palmeira, sem os quais o presente texto perderia muito. 


\section{Introdução}

Quando van Gogh escreveu a seu irmão Theodore em julho de 1880, tratou de enumerar as obras que estava então estudando; ele lia "a Bíblia e a Revolução Francesa de Michelet, e, no último inverno, Shakespeare e um pouco de Victor Hugo e Dickens, e Beecher Stowe e ultimamente Ésquilo e muitos outros, menos clássicos"1. Em conformidade com o relato, o emblemático nome de um dos tragediógrafos gregos aparece arrolado entre os autores autorizados a serem classificados como clássicos. Mas isto não é tudo: Ésquilo está situado entre os grandes clássicos, em oposição aos menores e àqueles sequer dignos de estudo.

Ao intérprete atual, um tal juízo poderá parecer mais ou menos aceitável conforme sua própria opinião e, no entanto, é este ajuizamento que apresenta o primeiro e maior entrave a uma leitura renovada da tragédia esquiliana. Isto se deve em especial à naturalidade com a qual se encara o arbitrário ato de nomeação, capaz de retirar um texto das circunstâncias originais de sua produção para fazê-lo figurar em um outro momento como clássico. Assim, aquilo que dizia respeito aos contemporâneos de Ésquilo fica agora cristalizado na monumentalidade mesma da tradição, a qual, com reconhecida legitimidade, impõe à tragédia um sentido outro, inteligível apenas nos quadros de subseqüentes epistemologias.

Uma reconhecida hermenêutica como a de Jean-Pierre Vernant favorece em muito a manutenção desta espécie de mal-entendido ${ }^{2}$. Insistindo na crença de que os gregos teriam sido responsáveis pela "invenção do Ocidente", ele acaba delegando a seus objetos o signo da origem. Clássicos, portanto, porque permitem melhor avaliar um suposto legado. Daí, se a política e a democracia gregas não são propriamente modernas, elas representam seu nascimento e trazem consigo uma essência a ser apontada pelo pesquisador ${ }^{3}$. Algo análogo

\footnotetext{
${ }^{1}$ GOGH, Vincent van. Cartas a Théo. Trad. Pierre Ruprecht, Porto Alegre: L\&PM, 1999, p. 23.

${ }^{2}$ Longe de ser uma característica específica da academia francesa, estas questões se apresentam arraigadas nos estudos clássicos de uma maneira geral. A referência a Vernant se deve à grande importância dos trabalhos deste helenista, canônicos na área. Não obstante, é interessante mencionar que dentre os antigos colaboradores de Vernant encontram-se os maiores adversários atuais de tal perspectiva. Sobre isso, DETIENNE, Marcel. Comparer l'incomparable. Paris: Seuil, 2000.

${ }^{3}$ Em recente e instrutiva entrevista ao L'Histoire, Vernant reafirma sucintamente o valor da política e democracia gregas. Reproduzido em português pela FOLHA DE SÃO PAULO. Os gregos inventaram tudo. São Paulo, 31 de Outubro de 1999, Mais!, pp. 5-6.
} 
ocorre com as tragédias, pois sendo elas produto de semelhante registro, conservam igualmente uma enigmática atualidade, um "sentimento trágico da existência" . O mesmo argumento surge mais uma vez em defesa da difusão do grego, do latim e da cultura clássica no ensino médio: perder este contado privaria novas gerações de uma herança que lhes cabe ${ }^{5}$.

De tão difundidos e institucionalizados, estes preconceitos continuam sendo reproduzidos quotidianamente. Eles chegam a ser tomados por obviedades! Por certo, não se trata aqui de negar que as tragédias de Ésquilo e os demais textos gregos e latinos antigos tenham sido, desde sua confecção, alvo de inúmeras e quase ininterruptas apropriações. Algo completamente distinto é acreditar na pureza destas leituras, na conservação de particularidades sócioculturais dos gregos durante os milênios seguintes. Como lembra Hartog ao estudar o exemplar contexto revolucionário francês, os referenciais denominados clássicos serviram aos mais diversos senhores, autorizando as mais distintas visões de mundo ${ }^{6}$. Logo, se há uma herança em jogo, esta não se encontra além das múltiplas interpretações elaboradas a partir desses textos.

Ainda assim, como se poderia cogitar em um primeiro instante, a multiplicidade do legado não está restrita a meras opiniões. Em se tratando de tragédia, não há conhecimento falso: todo ele corresponde invariavelmente às condições

\footnotetext{
${ }^{4}$ VERNANT, Jean-Pierre. Entre mito e política. Trad. C. Muraccho, São Paulo: Edusp, 2002, pp. 393-396.

${ }^{5}$ ROMILLY, Jacqueline de; VERNANT Jean-Pierre. (orgs.) Pour l'Amour du Grec. Paris: Bayard, 1999. Segundo Bourdieu, atribuir um valor imaterial, fora do mercado, para as línguas e culturas da Antigüidade clássica consiste em uma eficaz e corriqueira estratégia em prol da salvaguarda de um mercado de trabalho; Cf. BOURDIEU, Pierre. A produção e a reprodução da língua legítima. In: A economia das trocas lingüísticas. Trad. Sérgio Miceli, São Paulo: Edusp, 1998, pp 29-52. Além disto, tal postura contribui tanto para fundamentar uma divisão institucional dos saberes (o domínio do classicista); quanto para reforçar uma segregação social mais ampla, dotando, através do sistema educacional, uma elite ilustrada destes referenciais de cultura e opondo-a a um outro grupo, desprovido da valiosa herança. Deste último ponto decorrem algumas curiosas práticas de socialização do conhecimento, dentre as quais se notabilizam o ensino e a encenação dos clássicos às comunidades carentes. Procurando reverter desta forma a desigualdade social, alguns classicistas tomam o sintoma como a doença. Pode-se questionar até que ponto esta atitude não acabaria reforçando ainda mais a diferença entre aqueles que dispõem disto quando querem e os outros que dependem da bondade alheia.

${ }^{6}$ HARTOG. François. A Revolução Francesa e a Antigüidade. Humanas. Porto Alegre: UFRGS, v. 23, n. 1/2, 2000, pp. 13-44.
} 
dadas nas circunstâncias em que foi concebido. Em outras palavras, as várias leituras existentes são tão reais quanto o objeto sobre o qual recaem e, para uma melhor compreensão deste e daquelas, vale o esforço constante em prol do reconhecimento das particularidades de cada um dos momentos nos quais foram eles (objeto e leituras) produzidos. Separá-los possibilita ao interessado visualizar o campo epistemológico com o qual seu próprio tempo costuma ordenar o entendimento da tragédia e, em certa medida, subvertê-lo, denunciando nele os a priori vinculados aos conceitos e métodos aí empregados.

O bom herdeiro, diria Bourdieu parodiando Marx, não é aquele que se deixa herdar pela herança, mas aquele que a utiliza em prol de um bem maior, no presente caso, a ciência das obras trágicas. A análise da historiografia sobre Ésquilo, razão de ser deste trabalho, inicia com o itinerário até aqui sugerido. Procurando separar o próprio objeto das leituras posteriores, este texto não versa sobre o original grego, mas se preocupa com a análise crítica do campo epistemológico que marcou seu atual entendimento.

\section{A Definição de um campo epistemológico: o sublime exercício da tragédia}

Em 1968, em meio a uma acirrada discussão acerca das tragédias de Ésquilo, André Rivier publicou um artigo para se contrapor à postura defendida por Bruno Snell ${ }^{7}$. A divergência dizia respeito a um ponto considerado então fundamental: a manifestação da vontade como traço característico do gênero trágico. Snell já se notabilizara por relacionar o surgimento destas obras com a descoberta entre os gregos da vontade, da capacidade individual de fazer escolhas e assumir responsabilidades por elas ${ }^{8}$. Rivier, por seu turno, procurou reverter tal equação mostrando serem as noções de livre-escolha e ato voluntário estranhas à época de Ésquilo, bem como investindo na análise das coerções presentes nas tragédias. Para este autor, a ação trágica vem marcada por uma obrigatoriedade que é fruto da reverência ao sagrado, objeto da religião. Ou seja, os homens não agem por sua própria conta e risco, mas porque a ação se faz necessária.

\footnotetext{
${ }^{7}$ RIVIER, A. Remarques sur le "Nécessaire" et la "Nécessité" chez Eschyle. Revue des Études Grecques. n. 384-385, jan.-junho 1968, pp. 5-39.

${ }^{8}$ SNELL, B. The Discovery of the Mind. Trad. T. G. Rosenmeyer, Nova York: Dover, 1982, pp. 90-112.
} 
Deixando por agora de lado as minúcias destas duas posições, é possível reconhecer nelas semelhanças. Apesar de antagônicas, foi um campo epistemológico comum que as tornou possíveis, sendo ele caracterizado por uma explicação do fenômeno trágico a partir da ênfase na vontade individual e no embate entre ela e as instâncias superiores ao homem - deuses, destino, convenções sociais, entre outros. Se a resolução do conflito realiza o herói enquanto indivíduo (Snell), ou se o esmaga com o peso de algo infinitamente maior (Rivier), estas devem ser percebidas como resoluções radicais para uma mesma equação.

No âmbito da historiografia da tragédia, esta preocupação com a vontade só pôde se consolidar mediante o duplo impacto da Revolução Francesa e da filosofia crítica de Kant ${ }^{9}$. No entanto, para melhor visualizar a amplitude das novas questões aí surgidas, faz-se necessário um recuo estratégico rumo a meados do séc. XVIII, quando o quadro epistemológico a ser substituído no contexto dos eventos supramencionados ainda ostentava prestígio e coerência. Nesse ínterim, Lessing, figura central nas discussões estéticas de então, oferece uma importante síntese do paroxismo em que vivia a tradição da mimesis renascentista $^{10}$. Como entender suas particularidades?

Ut pictura poesis. A poesia (é) como a pintura. Assim a sentença horaciana aproximou as fronteiras das artes. Esta idéia o Renascimento italiano recuperou e adaptou, afirmando a superioridade da pintura sobre a palavra escrita e, com isso, a inegável perfeição do olhar perante a imaginação. Desde a competição entre as artes (paragone) iniciada por Da Vinci, uma tal idéia encontra-se cada vez mais repensada e sofisticada na Europa dos séculos XVII e XVIII.

Lessing, no limiar deste campo epistemológico, reafirma algumas destas premissas e subverte outras ao publicar seu Laocoonte ou sobre as fronteiras da pintura e da poesia em 1766. Sua reflexão acerca da arte ainda se compraz

\footnotetext{
${ }^{9}$ Os dois acontecimentos são tomados aqui como a ponta de um iceberg. Não são eles que provocam a ruptura, apenas anunciam e ilustram um processo social cujas minúcias escapam às pretensões deste texto.

${ }^{10}$ Para uma discussão pormenorizada acerca da tradição mimética renascentista e da importância de Lessing em seu derradeiro período, cf. SELIGMANN-SILVA, Márcio. Introdução/intradução. In: LESSING, Gotthold Ephraim. Laocoonte. Trad. Márcio Seligmann-Silva, São Paulo: Iluminuras, 1998, pp. 7-72.
} 
em repartir regras para os diferentes procedimentos miméticos, mas sua postura obriga-o a reconhecer nessas diferenças não uma relação hierárquica, mas uma mesma finalidade. A poesia e a pintura, dentro de suas especificidades, devem sempre atingir o belo.

Onde, porém, encontra-se material para fundamentar essa separação? Lessing é incisivo: no bom-senso dos antigos. A discussão acaba girando em torno de um conjunto de estátuas, supostamente erigido na antigüidade clássica, na qual se representa a história de Laocoonte e seus filhos sendo devorados por uma serpente (doravante, apenas Laocoonte). Comparando a escultura com a poesia greco-latina sobre o mesmo evento, em particular Virgílio, Lessing encontra os paradigmas tão desejados. A partir do Laocoonte e sempre o referenciando, a discussão toma vulto até dar conta de toda a produção artística.

A narrativa (poesia) contrapõe-se aqui à imagem (artes plásticas). Duas formas de expor distintas entre si que, por suas especificidades, também elegem objetos outros. Nas palavras do autor: "encontra-se uma diferença essencial entre elas; pois aquela é uma ação visível progressiva cujas diferentes partes acontecem uma após a outra na sequiência temporal, esta, em contrapartida, é uma ação visível inerte cujas diferentes partes se desenvolvem uma ao lado da outra no espaço"11.

Desta forma ficam estabelecidas diretrizes básicas para se alcançar o prazer por meio da beleza. A poesia o faz temporalmente, no tempo da narrativa; a pintura e a escultura, espacialmente, no espaço da representação imagética. Com isso, torna-se pouco recomendável usar a poesia de forma meramente descritiva, pois ela nunca o fará tão bem quanto a pintura. Por outro lado, as artes plásticas não podem dar conta de uma seqüência temporal, sendo crucial escolher um momento específico para ser retratado. O exemplo do Laocoonte permite um melhor entendimento das decorrências desta divisão.

O conjunto de estátuas mostra, segundo Lessing, não o ponto culminante da trama: a dor aguda dos personagens ao serem devorados pela serpente. Antes, retrata o momento imediatamente anterior, onde a dor final cede espaço à funesta luta ainda em curso. Evitam-se assim gritos e outras deformidades corporais consideradas pouco agradáveis, salientando a perfeição dos corpos e subentendendo a existência de uma continuidade para a história ${ }^{12}$.

\footnotetext{
${ }^{11}$ LESSING, Gotthold Ephraim. Laocoonte. op. cit., p. 190.

12 Ibid., pp. 89-103.
} 
Já a poesia, por seu caráter progressivo, joga com as sensações do público para lhe dar satisfação. Daí a vantajosa possibilidade de o feio ser exposto como artifício. Mas como o ridículo e o terrível, suas duas facetas, não podem gerar prazer sozinhos, eles instrumentalizam o poeta para, no decorrer do tempo, provocar alívio e alegria. Diz o autor: "aquilo que o poeta não pode usar por si mesmo (o feio), ele utiliza como um ingrediente para gerar e reforçar certos sentimentos mistos com os quais ele deve entreter na falta de sentimentos puros"13.

Para o ridículo, há a comédia. Para o terrível, a tragédia. No capítulo XXIII de seu Laocoonte, Lessing estabelece tal divisão e a justifica nos termos supracitados. O lugar reservado às tragédias aparece então desvelado: ela é uma forma de exposição poética, portanto progressiva, que se vale do terrível como artifício para gerar prazer.

$$
* * *
$$

A discussão oriunda do Renascimento não privilegia, como se viu, o embate entre a vontade individual e as outras instâncias superiores retratadas no enredo da tragédia. Quando muito, o conflito poderia ser tomado como um meio à disposição do poeta para, na sua imitação, atingir a finalidade da forma de exposição com a qual ele trabalha. Percepção estranha ao intérprete moderno, ela toma a tragédia apenas como instrumento para realizar o prazer por meio da beleza, e não como exercício intelectivo com o qual o homem coloca em questão sua própria natureza. É essa a transformação que a Revolução Francesa e a filosofia crítica de Kant vão catalisar no entendimento mais geral da arte; uma passagem, nos termos de Benjamim, da "forma de exposição" à "idéia das formas"14.

Longe de ser tão-somente fruto de uma mudança ideológica, o novo paradigma assinala um duro e decisivo golpe às bases sociais nas quais se organizavam e reproduziam idéias como as de Lessing ${ }^{15}$. Diante de uma contestação cada vez mais aguda, da qual são indícios os acontecimentos de 1781 (publica-

\footnotetext{
${ }^{13}$ Ibid., p. 253.

${ }^{14}$ Cf. BENJAMIN, Walter. O Conceito de Crítica de Arte no Romantismo Alemão. Trad. Márcio Seligmann-Silva, $2^{a}$ edição, São Paulo: Iluminuras, 1999, pp. 92-93.

${ }^{15}$ Isso não significa que ele e outros que operavam nos quadros conceituais renascentistas deixam de ser lidos e comentados por Goethe, Schiller e os demais leitores de Kant. O ponto fundamental é outro: suas considerações estéticas passam agora a ser lidas por um outro viés. Veja-se a sequiência do texto.
} 
ção da Crítica da Razão Pura) e 1789 (o início do processo revolucionário francês), é o próprio Antigo Regime que é posto em questão. O reflexo disto se fez sentir nas discussões sobre estética, pois era o ethos da nobreza que até então sustentava e consumia a maior parte do que se considerava arte e de sua crítica. Signo de distintiva notoriedade, a posse destes bens simbólicos atendia a uma etiqueta cortesã, à qual interessava naturalizar e absolutizar as diferenças entre os membros de sua confraria e os demais ${ }^{16}$.

Com a crise se desenrolando, os tradicionais emblemas de autoridade passaram a ser alvo de disputas e, consequentemente, re-leituras. A falência moral e institucional da aristocracia vai se firmando com sua gradual associação aos signos da repressão, da ignorância e da exploração. A partir daí, tal como nas Bodas de Fígaro de Beaumarchais, a direção dos acontecimentos é cada vez mais atrelada à vontade do homem ordinário, do povo. Astucioso e capaz de perturbar a ordem vigente, o herói desta comédia põe-na em cheque com palavras bastante reveladoras:

Só porque é nobre o senhor fica pensando que também é gênio!... Nobreza, dinheiro, posição, palácios, dão muito convencimento! O que é que o senhor fez para merecer tudo isso? Deu-se apenas o trabalho de nascer e nada mais: fora isso, é um homem perfeitamente medíocre! Enquanto eu, raios me partam, perdido no meio da multidão obscura, tenho de usar mais ciência e cálculo só para não morrer do que foram aplicados nos últimos cem anos para governar todas as Espanhas; e o senhor quer medir forças comigo! ${ }^{17}$.

Um tal esforço contestatório sustenta sua argumentação em uma percepção outra do indivíduo. As novas representações do homem comum lembram que há algo de comum a todos eles, algo anterior às distinções sociais provenientes

\footnotetext{
${ }^{16}$ Sobre o papel da etiqueta de corte francesa e alemã da segunda metade do século XVIII, ELIAS, Norbert. Etiqueta y ceremonial: conducta y mentalidad de hombres como funciones de las estruturas de poder de su sociedad. In: La Sociedad Cortesana. Trad. Guillermo Hirata, México, D. F.: Fondo de Cultura Economica, 1996, pp. 107-158. A encenação das tragédias e as discussões sobre suas especificidades miméticas devem ser tomadas como indícios dos espaços de sociabilidade nesta sociedade.

${ }^{17}$ BEAUMARCHAIS, Pierre A. C. de. As bodas de Fígaro. Trad. B. Heliodora, São Paulo: Edusp, 2001, p. 148. Interessante lembrar que a peça foi escrita no mesmo ano de publicação da Crítica da Razão Pura (1781).
} 
do berço. É sobre este mesmo princípio que Kant funda sua crítica transcendental, e a Revolução Francesa, suas diretrizes.

Quando os revolucionários franceses adotaram a Declaração dos Direitos do Homem e do Cidadão no verão de 1789, caminharam decididos a consagrar esta inovação: ela foi a primeira legislação a reconhecer direitos universalmente válidos para a totalidade dos indivíduos em um grande Estado europeu ${ }^{18}$. Logo em seu primeiro artigo vê-se como a liberdade e igualdade de direitos são concedidas a priori a todos desde o momento de seu nascimento - explicam-se aí as eventuais distinções sociais existentes como legítimas apenas se fundadas neste mesmo princípio, visando a utilidade comum. Em seguida, o texto defende o mesmo valor como guia das associações políticas dos homens: qualquer uma delas deveria defender os direitos pretensamente naturais e irrevogáveis do indivíduo, quais sejam, sua liberdade, propriedade, segurança e a resistência à opressão. Por fim, proclama a nação, enquanto materialização individualizada da coletividade, como guardiã suprema destes direitos ${ }^{19}$.

A filosofia crítica de Kant justifica sua razão de ser com um raciocínio análogo. Quando o filósofo nega a capacidade humana de conhecer o mundo exterior em si mesmo, fundamenta sua análise na descrição dos mecanismos com os quais os indivíduos constróem a priori tal conhecimento. Estes mecanismos, na forma como atuam antes da experiência, seriam a sensibilidade, dotando o sujeito da intuição espacial e temporal puras; o entendimento, com o qual se pode pensar eventuais sensações por meio de conceitos; e a razão, capaz de movimentar a intuição e o pensamento ao formular juízos conclusivos.

A análise destas três esferas nas quais se realiza o saber (sensibilidade, entendimento e a razão), caso venham a ser tomadas livres de qualquer interferência a posteriori, permitiria uma ciência apta a atuar negativamente com relação aos preconceitos atrelados, por meio de especulações, aos objetos exteriores ao homem: eles não possuem em si mesmos quaisquer atributos, pois

\footnotetext{
${ }^{18}$ Sobre o surgimento desta nova concepção de indivíduo, é salutar lembrar as legislações promulgadas nos Estados Unidos da América, bem como a influência destas no processo revolucionário francês. Cf. DUMONT, Louis. O individualismo. Trad. Álvaro Cabral, Rio de Janeiro: Rocco, 2000, pp.109-114.

${ }^{19}$ Estas discussões dizem respeito ao conteúdo dos três primeiros artigos da declaração. Sua escolha é estratégica, pois, como afirmou Thomas Paine, eles representavam o conjunto da declaração (os outros artigos eram como que casos especiais dos primeiros). Cf. PAINE, Thomas. Rights of Man. Nova York: Prometheus, 1987, p. 89.
} 
são os próprios sujeitos que lhes delegam suas características. Ainda assim, tal filosofia guardaria também uma dimensão positiva, já que os homens, deixando de agir em conformidade com o que acreditam ser esses objetos, poderiam discutir com mais propriedade acerca de uma nova moral sustentada nesta razão acurada por intermédio da crítica ${ }^{20}$.

O modus operandi deste raciocínio kantiano depende em absoluto da definição de atributos universalmente presentes em todos os homens. Para alcançar este resultado, o filósofo alemão abstrai de si mesmo esta generalidade. Diz ele: "ocupo-me unicamente da razão e do seu pensar puro e não tenho necessidade de procurar longe de mim o seu conhecimento pormenorizado, pois o encontro em mim mesmo" ${ }^{21}$. Triunfo do individualismo, esta postura faz do homem, enquanto indivíduo, ao mesmo tempo a origem de todo conhecimento possível e o objeto de conhecimento por excelência ${ }^{22}$. Saber sobre algo passa agora invariavelmente por um conhecimento de si enquanto sujeito de conhecimento, uma vez que o saber acaba concebendo o mundo exterior nos possíveis desdobramentos de um âmago individual comum a todos.

Nada poderia ser mais favorável à derrocada das bases sociais e simbólicas com as quais a aristocracia legitimava seu status, sua disposição (in)questionável para governar. Uma acirrada discussão sobre o limite moral das ações humanas acompanha de perto tais transformações. Se os antigos objetos de respeito e modelos de comportamento não são mais válidos, onde procurar substitutos? Surge aqui uma resposta inédita: naquilo que é inerente aos indivíduos. A arte não escapa às mudanças sociais e aos novos dilemas daí surgidos ${ }^{23}$; ela passa

${ }^{20}$ Cf. KANT, Immanuel. A crítica da razão pura. Trad. Manuela Pinto dos Santos e Alexandre Fradique Morujão, $4^{\text {a }}$ ed., Lisboa: Calouste Gulbenkian, 1997, p. 24, B XXV.

${ }^{21}$ Ibid., p. 7, A XIV.

${ }^{22}$ Se aplicada às diretrizes revolucionárias, esta sentença teria um conteúdo ligeiramente diferente. Seria então preferível dizer que o indivíduo é, ao mesmo tempo, sustentáculo de todas as leis e o alvo de sua proteção.

${ }^{23}$ Entre as transformações sociais mais significativas para o surgimento de uma nova idéia de arte, corroborando a ênfase aqui dada à nova noção de indivíduo, está a figura do artista moderno. Indivíduo autônomo e considerado particularmente sensível, ele passa a depender cada vez menos das estruturas de corte para ganhar seu sustento. Nos diversos campos da produção dita artística surgem, mais cedo ou mais tarde, outros mercados consumidores ávidos para celebrar, sustentar e consumir a individualidade do artista, o porta voz privilegiado do gênio da época. Sobre isso ELIAS, Norbert. Mozart, sociologia de um gênio. Trad. Michel Schröter, Rio de Janeiro: Jorge Zahar, 1995; e BOURDIEU, Pierre. As regras da arte. Trad. Maria Machado, São Paulo: Cia das Letras, 1996. 
mesmo a atuar como um dos foros privilegiados na reflexão sobre estes limites do agir. Nesta direção, os desdobramentos sociais e conceituais que engendraram a Revolução Francesa e a filosofia kantiana instrumentalizarão toda uma época (a atual) em sua leitura particular da tragédia grega. Esta forma de exposição conhecida de longa data passa então a figurar sob o signo do sublime ${ }^{24}$.

$$
* * *
$$

Já em 1792, apenas dois anos após a publicação da Crítica da Faculdade do Juízo de Kant, Schiller deu início à reinvenção da tragédia ${ }^{25}$. Como muitos poetas e filósofos de sua geração, ele assumiu o vocabulário e os problemas kantianos como herança, não obstante procurasse acrescentar algo à obra do mestre $^{26}$. Sua particular apropriação do sublime - noção proveniente da obra supramencionada - e a associação deste ao gênero trágico figuram entre tais inovações. Importantes como o são para o desenvolvimento do presente trabalho, para melhor entendê-las é mister se deter em uma breve análise das reflexões estéticas originalmente engendradas por Kant.

Quando formulou sua própria noção de sublime, este filósofo estava preocupado em explicar o que denominou de ajuizamentos estéticos. O belo e o sublime, seus dois possíveis momentos, seriam o produto final do impacto, no âmago individual, de certas impressões cuja particularidade reside no fato de que sobre elas, a despeito de todo o aparato sensível e conceitual disponível para decodificá-las, só é possível emitir algum parecer mediante o uso prazeroso da faculdade da imaginação. Nesse ínterim, a discussão trata não propria-

\footnotetext{
${ }^{24}$ A historiografia recente da tragédia grega vislumbra no sublime kantiano o marco divisório entre a tradição do ut pictura poesis, proveniente da recuperação da poética horaciana na Renascença, e a definição das preocupações atuais. Cf. MOST, Glenn. Da tragédia ao trágico. Filosofia Política. Rio de Janeiro: Zahar, série III, n. 1, 2001, pp. 2035; BENTHIEN, Rafael Faraco. Lessing e Schiller: duas idéias acerca da tragédia. In: Anais do X evento de iniciação científica. Curitiba: UFPR, 2002, p. 373.

${ }^{25}$ Vejam-se dois textos de Schiller de 1792: Acêrca da razão porque nos entretêm assuntos trágicos; Acêrca da arte trágica. In: SCHILLER, Friedrich. Teoria da Tragédia. Trad. Anatol Rosenfeld, São Paulo: Herder, 1964.

${ }^{26}$ Id. A educação estética do homem. Trad. Roberto Schwarz e Márcio Suzuki, $3{ }^{a}$ edição, São Paulo: Iluminuras, 1995, p. 24. Sobre isso, cf. igualmente a introdução da edição citada, cuja autoria é de Márcio Suzuki.
} 
mente da percepção desconcertante de algum objeto exterior, mas sim do fato de se extrair dela, via imaginação, algum deleite ${ }^{27}$.

Ao contrário do belo, o qual diz respeito à sensibilidade quanto ao formato do objeto (sua limitação), o sublime se produz frente ao incomensurável, ao absolutamente grande. Em sua verdadeira manifestação, como afirma Kant, o sublime "não pode estar contido em nenhuma forma sensível, mas concerne somente a idéias da razão, que, embora não possibilitem nenhuma representação adequada a elas, são avivadas e evocadas ao ânimo precisamente por essa inadequação, que se deixa apresentar sensivelmente" ${ }^{28}$. Quando se libera a imaginação com a percepção do colossal - seja esta a do infinito (impossível de ser avaliado esteticamente), ou de alguma força exterior ao homem (manifestações tais como o céu tempestuoso e o mar revolto) -, o indivíduo é colocado nesta estratégica posição que remete à sua pequenez.

Uma vez constatada essa inferioridade perante o mundo exterior, o homem pode tanto temer sua própria condição, como a transcender. Um exemplo da primeira atitude é a do crente supersticioso, o qual teme-se a si mesmo em reverência à vontade de Deus no mundo. No entender de Kant, ao agir assim ele acaba afastando de si a fruição estética, a qual só se faria presente caso o temor fosse abandonado em prol da constatação da sublimidade deste ente divino. Para tanto, seria preciso tomar os mecanismos da natureza não como concorrentes dos anseios dos homens, mas como pertencentes a uma outra esfera, apenas relativamente superior. Este mesmo crente poderia então se dar conta da sublimidade divina ao transcender sua condição, aproveitando a ocasião para vislumbrar os limites (físico e moral) de sua existência. O filósofo alemão elucida este exemplo na seguinte passagem:

A sublimidade não está contida em nenhuma coisa da natureza, mas só em nosso ânimo, na medida em que podemos ser conscientes de ser superiores à natureza em nós e através disso também à natureza fora de nós (na medida em que ela influi sobre nós). Tudo o que suscita

\footnotetext{
${ }^{27}$ KANT, Immanuel. Crítica da faculdade do juízo. Trad. Valerio Rohden e António Marques, $2^{a}$ edição, Rio de Janeiro: Forense Universitária, 2002, pp. 89-90, A 74. É importante aqui salientar que as condições para a produção de prazer com a arte dependem de uma certa atitude do espectador, a do desinteresse.
}

${ }^{28}$ Ibid., p. 91, A 77. 
este sentimento em nós, a que pertence o poder da natureza que desafia nossas forças, chama-se então (conquanto impropriamente) sublime; e somente sob a pressuposição desta idéia em nós e em referência a ela somos capazes de chegar à idéia da sublimidade daquele ente (Deus), que provoca respeito interno em nós não simplesmente através de seu poder, que ele demonstra na natureza, mas ainda mais através da faculdade, que se situa em nós, de ajuizar sem medo esse poder e pensar nossa destinação como sublime para além dele ${ }^{29}$.

O produto desta faculdade que permite ajuizar sem medo é a moral. Tratase, segundo Kant, da única esfera na qual o homem independe absolutamente do mundo exterior ${ }^{30}$. Da constatação disto se origina o prazer suscitado por intermédio do sublime: ele deve ser traduzido aqui como uma espécie de momento extremo, no qual o indivíduo se imagina confrontado por forças cuja extensão não consegue medir e, ainda assim, mantém sua dignidade, a invencibilidade de seu ânimo diante do perigo ${ }^{31}$. Caso este mesmo indivíduo sucumbisse apático ao terror, disto não poderia se originar nenhum prazer, mas apenas repugnância.

Deve-se tomar o cuidado, no entanto, para não confundir o sublime kantiano com o sentimento provocado por uma lição de moral. Para além desta, ele envolve essencialmente uma lição sobre a Moral, colocando em questão o próprio sentimento que leva alguém a agir. Como o homem é um ser dotado de uma natureza moral, o sublime o faz, mesmo que apenas por alguns instantes, ter plena ciência de sua condição, algo indispensável para o concurso da vida. Eis aí a razão porque Kant encontra nesta noção o mais elevado juízo de gosto (estético) ${ }^{32}$.

Chega-se então a outro ponto de fundamental importância: se na Crítica da Faculdade do Juízo o sublime é uma idéia que pode ser suscitada por

\footnotetext{
${ }^{29}$ Ibid., p. 110, A 109.

${ }^{30}$ Veja-se aqui o emblemático fragmento: "a lei moral me descobre uma vida independente da animalidade e mesmo de todo o mundo sensível, pelo menos, tanto quanto se pode inferir da destinação conforme a um fim da minha existência por essa lei, que não se restringe a condições e limites desta vida, mas se estende até o infinito". In.: Id. Crítica da razão prática. Trad. Artur Morão, Lisboa: Edições 70, pp. 183-184, A 287-291.

${ }^{31}$ Id. Crítica da Faculdade do Juízo, op. cit., p. 108-109, A 105-107.

${ }^{32}$ Ele requer, para Kant, mais cultura para se realizar que o juízo sobre o belo. Ibid., p. 111, A 111.
} 
manifestações artísticas, isto não se faz de todo necessário. Em verdade, lá, ela depende apenas do ânimo individual. Se este é capaz de se comover diante de uma obra poética, também pode sentir o mesmo diante de um vulcão em erupção, ou da escalada de uma montanha. Assim, a forma de exposição não é por si só garantia do prazer estético, por melhor que seja sua concordância com as regras do gênero. Sua eficácia depende tão-somente de imputar ao espectador uma idéia - no caso, o sublime. A contraposição à tradição mimética renascentista se torna ainda mais marcante nas próprias palavras de Kant:

Se alguém me lê sua poesia ou leva-me a um espetáculo que ao final não satisfará meu gosto, então ele pode invocar Batteux ou Lessing ou críticos do gosto ainda mais antigos e mais famosos e todas as regras estabelecidas por eles como prova de que sua poesia é bela; também certas passagens que particularmente não me aprazem podem concordar com regras da beleza (assim como lá são dadas e reconhecidas universalmente): eu tapo meus ouvidos, não quero ouvir nenhum princípio e nenhum raciocínio, e antes admitirei que aquelas regras dos críticos são falsas ou que pelo menos aqui não é o caso de sua aplicação, do que devesse eu deixar determinar meu juízo por argumentos a priori $^{33}$.

Se Kant enfrenta os princípios do quadro epistemológico renascentista professando sua fé em idéias inerentes aos sujeitos (e não em cânones formais), Schiller observará mais tarde, ainda que sem invalidar as indicações deste filósofo, uma íntima relação entre as formas e as idéias. Sua exposição recai sobre a maneira particular com que cada gênero é organizado segundo regras miméticas. A ênfase dada a estas regras e sua eficácia na imitação não são, porém, as mesmas de outrora. A tragédia desembaraça-se aqui de todos os cânones indispensáveis no passado (o objeto representado, os recursos utilizados para representá-lo, a dinâmica do enredo, entre outros) e passa agora a depender fundamentalmente de seu conteúdo, do qual poderia surgir, dependendo do espectador, o sublime. Daí, como em Kant, o papel crucial do âmago individual na fruição da arte. Uma eficaz imitação depende se a obra de arte suscita, ou não, idéias ${ }^{34}$.

\footnotetext{
${ }^{33}$ Ibid., p. 131, A 141.

${ }^{34}$ Para tanto, cf. os textos citados na nota 26.
} 
Em conformidade com as caraterísticas da tragédia, Schiller vê se apresentar nela uma situação extrema. O herói, sofrendo, entra em um conflito contra a natureza exterior a si. Por ter se originado de um acaso, de algo absolutamente maior, o que tenderia de início a causar repulsa ao espectador, a dor do personagem, transforma-se em comoção ${ }^{35}$. Mas por que isto ocorre?

De acordo com Schiller, a razão para tanto reside na própria essência do homem, segundo a qual ele "é o ser que quer"36. Querer, manifestar vontade, passa a ser considerado a matéria-prima de toda ação humana, contra a qual apenas violentamente podem se impor empecilhos. Este substrato, no entanto, traz o conflito como algo intrínseco. É, afinal, esta sua própria essência que, em uma constante reivindicação da liberdade, evoca a seguinte contradição: é possível querer, mas não ter tudo.

Para combater tal impasse, dois caminhos antagônicos são propostos: ou a dominação da natureza, única força capaz de se opor ao homem, ou o afastamento dela. Caso dependesse apenas da primeira opção, seria ele incapaz de ser livre, posto ser a natureza infinitamente mais forte na sua esfera de ação. Já no segundo caso está implícita uma solução: ao se afastar da natureza, o indivíduo pode perceber os diferentes campos em que ambos atuam e, respeitando a diferença, passar a agir em consonância com ela ${ }^{37}$.

Também para Schiller o campo específico no qual o homem se afasta da natureza é a moral. O trágico, por ser capaz de despertar o sublime em cada indivíduo, consistiria em uma melhor compreensão do que separa o homem físico (reino da necessidade), do homem moral (reino da liberdade). Ele trataria na prática não do rompimento com o mundo sensível, de onde provém aquilo

\footnotetext{
${ }^{35}$ A não observação destas prerrogativas produz a tragédia o sem trágico. É o caso, segundo Schiller, da tragédia francesa, na qual o herói é desumanamente digno: ele não erra e não sofre, pois atua apenas de acordo com sua moral. Em sendo assim, o conflito entre natureza e o homem é irreconciliável a priori. Para que isto não ocorra, a moral precisa ser contraposta ao mundo exterior, resistir a ele, possibilitando então a percepção do que há de patético e grandioso na vida. Sobre isso, SCHILLER, Friedrich. Teoria da tragédia. op. cit., pp. 103-109.

${ }^{36}$ A discussão sobre a vontade humana e seus contornos trágicos é bem desenvolvida em Id. Acêrca do Sublime. Teoria da tragédia. op. cit., p. 45. Publicado em 1801, este texto é um dos últimos em que Schiller trata da tragédia e também aquele em que esboça de maneira mais sistemática suas idéias, revendo as posturas anteriores.

${ }^{37}$ Ibid., p. 47.
} 
que mantém a vida, mas da harmonização entre esta esfera e a vontade humana, sem a qual não há dignidade. Assim sendo, a representação trágica de um eventual conflito entre vontade humana e natureza produz as condições necessárias para a conscientização dos limites de ação dos homens. Seu resultado final é uma vontade auto-reflexiva, consciente de suas limitações e infinitamente livre nelas. Eis aí a fusão entre a tragédia e o sublime kantiano.

Os temas capazes de desencadear um tal sentimento são muitos, mas Schiller enuncia sua essência em um trecho revelador:

O que nos ajuda a travar êsse conhecimento é o terrível e magnífico espetáculo da transformação que tudo destrói e reconstrói, para vir de nôvo e destruir - o espetáculo da calamidade, ora minando vagarosamente, ora investindo com celeridade, e ainda as cenas patéticas da humanidade em luta contra o destino, da irresistível fuga da felicidade, da segurança burlada, da injustiça triunfante e da inocência vencida, coisas que a história apresenta abundantemente e que a arte trágica, imitando, põe diante de nossos olhos. ${ }^{38}$

$$
* * *
$$

A acepção moderna da tragédia está aí. Poder-se-ia mesmo arriscar uma definição sucinta: trata-se de um gênero no qual está representado o fatídico embate entre a vontade de um indivíduo e forças superiores a ele, possibilitando o sublime prazer em outro indivíduo, o espectador, quando este vê no enredo trágico o espelho da (sua própria) condição humana. Colocando o problema desta forma, a historiografia da tragédia tendeu a ler suas diversas manifestações como oriundas de um ponto comum. Já que a essência humana é por definição invariável, os mesmos dilemas morais teriam de ser enfrentados sempre que a tragédia se manifestasse por intermédio do sublime. Vale dizer: se o indivíduo, enquanto tal, é idêntico a priori a todos os seus contemporâneos e antepassados, e se a tragédia coloca em questão essa sua situação (física e moral) de indivíduo, não é de se estranhar uma unidade para o gênero trágico.

Partindo desta idéia, Schiller definiu regras universalmente válidas para a tragédia. Não foi ele, no entanto, o único responsável pela consagração da nova

\footnotetext{
${ }^{38}$ Ibid., p. 62.
} 
hermenêutica. Seu sucesso deveu muito à acolhida que suas idéias tiveram a partir daí, à institucionalização de seu pensamento. Interessantes nesta direção são as reflexões engendradas por seus contemporâneos, os românticos do círculo de Jena, sobre noções como sublime, tragédia e seus derivados.

Por ocasião da publicação dos fragmentos críticos na revista Athenäum, em 1798, vários destes termos se fizeram presentes. Em alguns trechos eles estão associados ao caráter nacional do povo no qual se manifestam ${ }^{39}$. Em outros, implicam na discussão sobre a excelência do gênero trágico e seu lugar dentre as diversas manifestações artísticas. Nesse ínterim, August Schlegel chega afirmar que "é justamente nos elementos conflitantes (...) que se mostra a harmonia interna do espírito. Ou se negará que há grandeza serena e nobre nas tragédias de Sófocles justamente porque são altamente trágicas?" ${ }^{40}$.

$\mathrm{O}$ aspecto pouco sistemático de suas discussões acaba afastando, em um primeiro momento, estes filósofos de uma análise mais detida da tragédia. Terse-ia de esperar por Schelling que, entre 1802 e 1805, procurou reunir várias impressões dispersas em um apanhado geral sobre o assunto. A ocasião se apresentava sob a forma de um curso de estética, no qual seu ministrante mostra familiaridade com as preocupações de Schiller e dos românticos de Jena ${ }^{41}$.

Neste contexto, Schelling defende o conflito entre a vontade individual (liberdade) e as forças exteriores ao homem (necessidade) como principal característica da tragédia. Para suscitar o sublime, no entanto, tal embate deve ser presidido pela fatalidade. Esta impõe ao protagonista um único caminho a ser seguido, ao qual ele adequa, a despeito de toda luta, sua liberdade. Sobre

\footnotetext{
${ }^{39}$ No fragmento 199 é o sublime que está vinculado ao caráter nacional dos ingleses; já os de número 138, 141 e 424 relacionam a tragédia com esta questão. No segundo destes últimos fragmentos reforça-se a crítica de Schiller às tragédias francesas (vide nota 36). In.: SCHLEGEL, Friedrich. Dialeto dos fragmentos. Trad. Márcio Suzuki, São Paulo: Iluminuras, 1997, respectivamente nas páginas 80, 69, 70 e 134. Também Novalis fará esta associação, vinculando a produção de tragédias ao auge de um povo e a de comédias, à seu enfraquecimento. NOVALIS, Friedrich von Hardenberg. Pólen. Trad. Rubens Filho, 2a edição, São Paulo: Iluminuras, 2001, p. 132.

${ }^{40} \mathrm{O}$ trecho citado faz parte do fragmento 310, publicado em SCHLEGEL, Friedrich. Dialeto dos fragmentos, op. cit, pp. 103-104. O mesmo tema pode ser encontrado nas páginas 77-78 (fragmento 187), 89 (240) e na 27, constando com o número 45 dentre os fragmentos publicados em uma outra coletânea, intitulada Lyceum.

${ }^{41}$ SCHELling, F. Filosofia da arte. Trad. Márcio Suzuki, São Paulo: Edusp, 2001, pp. 316-330.
} 
isso, afirma o autor: "o maior pensamento e a maior vitória da liberdade é suportar voluntariamente também o castigo por um crime inevitável, para assim, na perda de sua própria liberdade, demonstrar essa mesma liberdade e sucumbir, porém, ainda com uma declaração de sua vontade livre" ${ }^{\text {42 }}$. Desta maneira o destino trágico une duas diferentes lógicas: a que preside o âmago individual (a moral) e a das causalidades do mundo. $\mathrm{O}$ triunfo concomitante destas duas esferas permite tanto o cumprimento da coerção exterior, quanto a afirmação do livre-arbítrio ${ }^{43}$.

Se a descrição do conteúdo trágico e de seu impacto na consciência individual é bastante próxima em Schiller e Schelling, também o será a observação dos aspectos exteriores das obras de arte. Nessa direção, um poeta seria considerado bom se, como os gregos fizeram com excelência, conciliasse a idéia de sublime com sua apresentação formal; ao passo que o mau se preocuparia apenas com este último ponto. Vê-se novamente a autonomia da idéia da forma (o trágico-sublime), em detrimento da forma de exposição ${ }^{44}$.

\section{Variações sobre um tema kantiano}

A percepção da tragédia no decorrer do século XIX não é, no entanto, estática. Apesar de manterem o mesmo problema essencial - o impacto subjetivo do embate entre a vontade individual e as forças exteriores ao homem -, os vários intérpretes sistematizaram suas digressões de maneiras diferentes, enfatizando termos e recortes novos. Dentre eles, um se mostrará decisivo para a leitura acadêmica da tragédia no início do século seguinte: Friedrich Nietzsche.

O Nietzsche interessante para o presente trabalho é aquele de 1872, ano em que publica um de seus primeiros textos: O Nascimento da Tragédia ${ }^{45}$. Como o próprio autor veio a reconhecer mais tarde, trata-se de uma obra concebida em meio às influências de Kant, Schopenhauer e vários expoentes da

\footnotetext{
${ }^{42}$ Ibid., pp. 318-319.

${ }^{43}$ Nas palavras de Schelling, "que esse culpado inocente assuma voluntariamente a punição, isso é o sublime na tragédia; somente por meio disso a liberdade se transfigura em suprema identidade com a necessidade". Ibid., p. 320, (itálico no original).

${ }^{44}$ Ibid., pp. 322-327.

${ }^{45}$ NIETZSCHE, Friedrich. O nascimento da tragédia. Trad. Jacó Guinsburg, $2^{\text {a }}$ ed., São Paulo: Cia das Letras, 1999.
} 
dita geração Sturm und Drang ${ }^{46}$. Disto decorrem significativas referências aos poetas e filósofos já mencionados, bem como apropriações de temas e conceitos por eles engendrados ${ }^{47}$. Resta saber então como Nietzsche se mantém fiel a este legado e como lhe acrescenta algo.

No tocante à contribuição específica do filósofo à historiografia da tragédia, esta tem início no fato de ter ele cunhado os termos apolínio e dionisíaco. Uma tal dicotomia foi aqui forjada para auxiliar o entendimento da maneira específica com a qual os gregos manifestaram duas tendências estéticas universalmente dadas aos homens. Representando-as por intermédio de dois de seus deuses, Apolo e Dionísio, teriam eles tomado um caminho único: ao invés de afirmar a supremacia de um deles sobre o outro, alternaram seus períodos de domínio até que, por fim, uma aliança entre ambos foi materializada com o surgimento da tragédia ${ }^{48}$. Mas qual o significado desta bipartição e por que teria ela validade universal?

Segundo Nietzsche, a primeira destas tendências (o apolínio) tornaria possível o dito principium individuationis. Em outras palavras, ela permitiria ao homem reconhecer a si mesmo e a tudo o que o cerca em sua aparente especificidade, na ilusão de uma individualidade. Quando este poder criador surge mediante o esforço do artista, abre-se espaço para o desenvolvimento das artes plásticas, do "mundo figural do sonho". A arquitetura dórica, as elegias de Píndaro, a épica de Homero; aí estão enumeradas várias manifestações de uma

\footnotetext{
${ }^{46}$ Estas indicações se encontram em um posfácio de 1888, publicado em Ibid., pp. 13-23. Dentre os expoentes da Sturm und Drang (Tempestade e Impeto), movimento literário e filosófico alemão da virada do séc. XVIII para o XIX, encontravam-se Schiller e Goethe. ${ }^{47}$ Um deles, Schiller, interessa em particular à presente discussão. Nietzsche o cita com uma considerável frequiência. As referências mais sugestivas encontram-se em Ibid, p. 43 (Schiller fornece aqui alguma luz sobre o aspecto dionisíaco da poesia da Arquíloco); 53-4 (contraposição entre as leituras de A. W. Schlegel e Schiller acerca do coro trágico - Nietzsche concorda com este último); 57 (considera-se Schiller certo sobre o surgimento da tragédia); 116 (vale-se de Schiller para explicar a diferença entre o idílio e a elegia); 120 (ao lado de Goethe e Winckelmann, Schiller é considerado um pioneiro no resgate da cultura trágica grega); e 133 (Nietzsche discorda de Schiller quando este toma a arte como tendo uma finalidade moral). $\mathrm{O}$ vocabulário utilizado pelo filósofo alemão também é bastante instrutivo; salienta-se aqui a usual presença da idéia de sublime. Sobre isso, em especial, Ibid., p. 56 (enquanto domesticação artística do horrível) e 123 (relacionada com o efeito provocado pela tragédia).

${ }^{48}$ Nietzsche localiza em outras localidades e em outros tempos a existência destas duas tendências (ele fala de festas dionisíacas em Roma e Babilônia, Ibid., p. 33). A especificidade da trajetória grega está condensada em Ibid., p. 42.
} 
arte formal, austera e descritiva, empenhada em instituir a fronteira entre os seres, colocando cada um deles em seu devido lugar ${ }^{49}$.

O dionisíaco, por sua vez, tomaria um caminho outro. Cabe a ele, ao evocar o princípio caótico e arbitrário do mundo, dissolver a imagem do indivíduo no coro da coletividade. Na arte engendrada por esta tendência não há espaço para o particular, mas apenas para a sua desintegração na natureza. Nela, a subjetividade do artista é abandonada para que, uma vez liberto de sua vontade individual, possa ele encarnar em si a Verdade e a Vontade do Uno-primordial. Nas palavras de Nietzsche, "o homem deixa de ser artista para se tornar obra de arte" ${ }^{50}$. Trata-se, enfim, da arte do êxtase e da embriaguez. Enquanto o apolínio está conectado às artes plásticas, à ilusão imagética, o dionisíaco se faz presente com a música, na qual a individualidade de cada nota perde sua importância para a relação harmônica que as transcende ${ }^{51}$. Isto justifica a identificação do dionisíaco grego com Arquíloco, o poeta lírico do escárnio e dos cantos populares $^{52}$.

Cada uma destas duas tendências tenderia a anular a outra sempre que se fizesse presente. Daí a possibilidade aberta ao filósofo de, ao perceber qual delas predomina, caracterizar as criações artísticas de um povo. Torna-se assim mais compreensível o caráter sui generis desenvolvido pela cultura grega: ela distancia-se das outras ao fundir os dois princípios em um mesmo evento, a tragédia ática. Nele, apresenta-se como enredo a trajetória de um herói que, sendo a mais elevada aparição da vontade, "é, para nosso prazer, negado, porque é apenas aparência, e a vida eterna da vontade não é tocada de modo nenhum por seu aniquilamento" ${ }^{53}$. Representa-se desta maneira, ao mesmo tempo, a imagem individual (apolínea) de um herói dotado de existência e desejos

\footnotetext{
${ }^{49}$ Apesar de diluídos no texto, Nietzsche concentra boa parte de seus argumentos em Ibid, pp. 27-38.

${ }^{50}$ Ibid., p. 47.

${ }^{51}$ O vínculo entre o dionisíaco e a música é crucial para a compreensão desta obra de Nietzsche. É preciso notar, porém, que está aí em jogo uma definição muito particular de música, orientada pela predominância da harmonia frente à melodia, ritmo e timbre. Sobre os aspectos formais de tal percepção, generalizada na Europa de Nietzsche e Wagner, cf. WISNIK, José M. $O$ som e o sentido. $2^{2}$ ed., São Paulo: Cia das Letras, 2001, pp. 113-170.

${ }^{52}$ NIETZSCHE, Friedrich. O nascimento da tragédia. op. cit., pp. 44-46.

${ }^{53}$ Ibid., p. 102.
} 
efêmeros, bem como um desfecho no qual se desvelam a Vontade e o Destino do mundo, as forças dionisíacas ${ }^{54}$.

A tragédia também tendeu a reproduzir tal mescla de aspectos apolíneos e dionisíacos quanto ao seu aspecto formal. O teatro antigo garantiu esta união ao incorporar os atores individuais, com seus diálogos e gestos, à musicalidade da "multidão dionisíaca" representada pelo coro ${ }^{55}$.

Por meio desta nova arte os gregos puderam vislumbrar o aspecto caótico do mundo em si mesmos e, ainda assim, não serem por ele dissolvidos. Eles estariam fadados a permanecer seguros, observando a realidade denunciada na tragédia por intermédio do véu da individuação, elemento indispensável à continuidade da vida. Valer dizer: o herói individualizado lembra-lhes de tudo o que há de ilusório em suas vidas, bem como da necessidade desta ilusão para tolerar a arbitrariedade do mundo. Esta arbitrariedade, por sua vez, incita-os a não se tornarem escravos de suas ilusões, mas a criar a partir do fundo caótico no qual elas se movimentam ${ }^{56}$. Do desdobramento deste raciocínio decorre a sugestão de Nietzsche de que o teatro deva se preocupar pouco com a formação moral de seu povo, pois também ela é arbitrária e passageira. Segundo o filósofo alemão, tal preocupação seria mesmo um signo de degeneração; a verdadeira arte culmina com a constatação de que a vida e a própria arte são muito superiores à moral ${ }^{57}$.

\footnotetext{
${ }^{54}$ De acordo com Nietzsche: "No efeito conjunto da tragédia, o dionisíaco recupera a preponderância; ela se encerra com um tom que jamais poderia soar a partir do reino da arte apolínea. E com isso o engano apolíneo se mostra como ele é, como o véu que, enquanto dura a tragédia, envolve o autêntico efeito dionisíaco, o qual, todavia, é tão poderoso que, ao final, impele o próprio drama apolíneo a uma esfera onde ele começa a falar com sabedoria dionisíaca e onde nega a si mesmo a sua visibilidade apolínea. Assim, a difícil relação entre o apolíneo e o dionisíaco na tragédia poderia ser realmente simbolizada através de uma aliança fraterna entre as duas divindades: Dionísio fala a linguagem de Apolo, mas Apolo, por fim, acaba falando a linguagem de Dionísio: com o que fica alcançada a meta suprema da tragédia e da arte em geral." Em Ibid., pp. 129-130 (itálico não consta no original).

${ }^{55}$ A respeito dos significados com os quais se empregam as palavras herói e coro, bem como sobre a oposição entre ambas, Ibid., pp. 56-69.

${ }^{56}$ Em Nietzsche, o artista trágico "qual uma exuberante divindade da individuatio, cria as suas figuras, sentido em que mal poderia se conceber sua obra como 'imitação' da natureza - tal como depois, porém, o seu imenso impulso dionisíaco engole este mundo de aparência, para deixar pressentir por trás dele, e através de sua destruição, uma suprema alegria artística primordial no seio do Uno-primordial”. Ibid., p. 131.

${ }^{57}$ Ibid., p. 133 e seguintes. Este ponto é um dos poucos em que Nietzsche critica aqui a geração de Schiller. Sua hermenêutica, porém, reproduz parte significativa das idéias de outrora: nos dois casos a arte trágica é entendida como um instrumento de transcendência, capaz de evidenciar uma suposta natureza humana - seja ela moral, ou não.
} 
Uma vez discutido o sentido da bipartição apolíneo/dionisíaco, resta ainda ver como Nietzsche delega a ela uma pertinência universal. A esse respeito, aquilo que o filósofo chama de socratismo pode fornecer alguma $\mathrm{luz}^{58}$. Com esta noção ele sintetiza a tendência antiestética por excelência, uma espécie de antípoda da tragédia sustentada na busca constante (e cega) da verdade. Tal verdade, no entanto, não guarda qualquer vínculo com aquela revelada pela arte trágica: ela é verdade do homem teórico (passível de ser ensinada), por oposição à do artista (instintiva e indissociável da vida).

Seus primórdios remetem a Sócrates e Eurípides. Foram eles que, incapazes de compreender o real significado das tragédias, teriam-nas deturpado e denunciado como perigosas. Aceitando este juízo, o homem grego pôde então se afastar de seu cotidiano artístico para se lançar ao claustro de Alexandria. Lá, alheio ao mundo exterior, ele procuraria em vão saber sobre a Verdade deste mesmo mundo.

É o conflito entre essa cultura teórica de Alexandria e a trágica que Nietzsche procura salientar em seu próprio tempo. A cultura do homem teórico teria tido continuidade com a ciência moderna, estando esta em oposição à práxis do músico e do filósofo. Nesse ínterim, Kant, Schiller e os demais filósofos alemães contribuíram com o renascimento da tragédia levando a compreensão do homem teórico ao seu limite ${ }^{59}$. Bach, Beethoven e, sobretudo, Wagner, teriam feito o mesmo ao manterem acesa a chama dionisíaca da música ${ }^{60}$. Amparado por estes artistas-sacerdotes, o povo alemão teria à sua disposição todos os instrumentos para efetuar a volta à sua terra prometida e garantir o re-surgimento da antiga Época de Ouro e de sua respectiva arte.

$* * *$

Quando contraposta às leituras fundantes do campo epistemológico que marcou a atual compreensão das tragédias, a análise engendrada por Nietzsche tem duas importantes virtudes. Por um lado, anuncia de forma paradigmática o esforço de acrescentar algo (conceitos e problemas) ao entendimento da tragédia. Por outro, também de maneira exemplar, aponta para a incapacidade do crítico em se libertar das bases sobre as quais originalmente se sedimentou tal entendimento.

\footnotetext{
${ }^{58}$ Sobre o socratismo, cf., em especial, Ibid., pp. 91-96.

${ }^{59}$ Ibid., pp. 108-112.

${ }^{60}$ Wagner foi mesmo além: refundiu música e teatro. Ibid., pp. 112-120.
} 
Em Nietzsche, por exemplo, a dicotomia apolíneo/dionisíaco se torna mais compreensível se pensada por este duplo viés: ela inova, mas acaba reproduzindo muito do papel outrora reservado à noção de sublime. Quanto ao conteúdo da tragédia, se antes a vontade individual do herói se debatia contra a do mundo exterior, agora é a ilusão da individuação (apolíneo) que se dissolve na Verdade (dionisíaca) do mundo. De tal conflito decorre também um efeito muito próximo ao do sublime no espectador: se ele antes se prestava à delimitação das esferas de ação do homem físico (reino da necessidade) e moral (reino da liberdade), agora distingue o caráter caótico do mundo, da arbitrariedade dos signos com os quais o homem trágico (livre-pensador e artista) criativamente se protege.

Ainda assim, O Nascimento da Tragédia inegavelmente acrescenta algo à discussão acerca da tragédia. Seu autor, afinal, não é nem Kant, nem Schiller, tampouco escreve para o mesmo público, usa estritamente a mesma linguagem e se movimenta nos mesmos espaços sociais destes filósofos. A questão, porém, não se restringe a isso! Deve-se também procurar problematizar em que medida tais inovações acabam reafirmando tacitamente uma antiga hermenêutica. Ou seja, fundamental é saber até que ponto o estudioso da tragédia acaba incorporando um esquema interpretativo dado a priori para, sem ser capaz de vislumbrar sua dimensão, reapresentá-lo sob um novo invólucro.

Sob este ponto de vista não seria Nietzsche, no tocante à historiografia da tragédia, uma variação sobre um tema kantiano? Não se trataria aqui de mais um dos casos, não tão inconstantes assim, em que a tradição se fortalece por intermédio do suposto iconoclasta? E, por fim, não seria esta a triste sina dos estudos clássicos: atribuir, atualizar e eufemizar valores apriorísticos, histórica e socialmente mapeáveis, aos seus objetos de estudo?

Temendo isto que Hannah Arendt chama com propriedade de a "vingança da tradição", é em direção à atualidade que o presente trabalho se encaminha. Se até então nele se procurou retratar um leque de noções e o nexo lógico que as une no entendimento atual da tragédia, a partir de agora se problematizará como esta herança é gerenciada pela leitura acadêmica da tragédia no século XX.

${ }^{61}$ ARENTD, H. Entre o Passado e o Futuro. Trad. M. Barbosa, São Paulo: Perspectiva, 1972, pp. 43-68. 
Para tanto, em conformidade com o recorte temático aqui sustentado, restringir-se-á a discussão a alguns textos-chave sobre as tragédias de Ésquilo. O recorte é estratégico e de uma ampla abrangência: em sendo ele o mais antigo dos tragediógrafos cuja produção é hoje conhecida, seus textos tenderiam naturalmente a apontar os elementos puros, originais do gênero ${ }^{62}$. De fato, como se verá em seguida, é a partir da análise dos textos de Ésquilo que boa parte dos problemas originalmente circunscritos por Kant e Schiller vão se consolidar como temas centrais nas discussões acerca da tragédia.

$$
* * *
$$

Dentre os estudiosos que conservaram esta interpretação da tragédia no século XX, Bruno Snell foi um dos primeiros a ganhar notoriedade. Embora tenha iniciado sua reflexão sobre Ésquilo na Alemanha da década de $1920^{63}$, parte de seus textos mais difundidos sobre o tema datam do período em que se desenrolava a Segunda Guerra Mundial. Uma vez findo o conflito e reestruturado o universo acadêmico europeu, o helenista pode então reunir tais textos em uma obra de sua inteira autoria, Die Entdeckung des Geistes ${ }^{64}$.

A relação de Snell com a cultura grega clássica e com a historiografia da tragédia bem poderia ser sintetizada na frase de abertura deste livro: "o pensamento europeu teve início com os gregos" $"$. Tornar o legado público e corrigir eventuais enganos de intérpretes anteriores é sua pretensa contribuição aos estudos clássicos, a qual faz da tragédia esquiliana um importante ponto de inflexão. Ver-se-á na seqüência como ele procede para alcançar este duplo objetivo.

\footnotetext{
${ }^{62}$ Em Nietzsche, mais uma vez exemplar, Ésquilo é o protótipo da original e bem sucedida união entre Apolo e Dioniso. Cf. NIETZSCHE, Friedrich. O nascimento da tragédia. op. cit, pp. 66-72; 87-91.

${ }^{63}$ SNELL, Bruno. Aischylus und das Handeln im Drama. Leipzig: Philologus, Supplementband XX, Heft 1, 1928.

${ }^{64}$ Literalmente: o descobrimento do espírito. A edição utilizada para o presente trabalho é uma tradução inglesa fiel à segunda edição do livro (1948), Id. The Discovery of the Mind. op. cit.

65 "EUROPEAN thinking begins with the Greeks". (caixa alta no original) Id. The Discovery of the Mind, op. cit., p. v (a tradução é nossa).
} 
Quanto à retificação dos equívocos anteriores, Snell dialoga diretamente com os problemas e conceitos tradicionais ${ }^{66}$. A esse respeito é particularmente instrutivo um artigo de 1937, o sexto capítulo de sua coletânea ${ }^{67}$. Nele, o autor discute o desenvolvimento da crítica de arte sobre a tragédia, dando especial ênfase à argüição favorável ou contrária aos antigos tragediógrafos. Indo de Aristófanes a Nietzsche, constata uma alternância sucessiva de juízos de valor sobre o teatro antigo, a qual encampou ora o triunfo de Ésquilo sobre seus rivais, ora o de Eurípides. Sobre uma tal competição, o autor procura demostrar sua falta de sentido frente à constatação de que Ésquilo e Eurípides são respectivamente o início e o desdobramento final de um mesmo processo. Como permaneceram incapazes de perceber tal teleologia, os críticos opuseram-nos erroneamente $^{68}$. Fica então a pergunta: qual o teor deste processo incompreendido pela historiografia da tragédia e de que forma poderia ele dissipar os equívocos já cometidos?

Esta questão traz à superfície aquilo que Snell entende como o maior legado grego: a descoberta da vontade, da capacidade humana de fazer escolhas e assumir responsabilidade por elas. Antes da tragédia esquiliana não há qualquer indício do ato decisório individual. Em Homero, ou são os deuses os responsáveis diretos por qualquer ação humana, ou estas são fruto de um código externo, autorizado a restringir a escolha do herói a uma só alternativa ${ }^{69}$. Na poesia lírica, apesar de marcada pela percepção primeira do indivíduo, os deuses continuam representando importante papel na comunicação das sensações e opiniões

\footnotetext{
${ }^{66}$ Em seus textos são feitas constantes remissões a Goethe, Nietzsche, os românticos de Jena, Lessing, Winckelmann, Herder, entre outros (em decorrência de sua quantidade e difusão, elas não serão aqui descriminadas). Quantos aos termos empregados, utilizamse com freqüência as noções de vontade e sublime. Esta última, no entanto, está aqui desprovida de seu aspecto técnico e, no mais das vezes, poderia ser traduzida por adjetivos como suprema, insuperável. Sobre isso, veja-se Ibid., p. 114 (qualificativo do ideal poético reforçado por Aristófanes) e 301 (relacionada à poesia de Virgílio).

${ }^{67}$ SNELL, Bruno. Aristophanes and Aesthetic Criticism. In: Ibid., pp. 113-135.

${ }^{68}$ Em um dos estratégicos exemplos mencionados, os românticos alemães enxergaram em Ésquilo um tratamento poético do irracional (da coerção divina sobre as ações humanas, do dionisíaco), ao passo que Eurípedes remeteria à degeneração provocada pela pobreza estética do pensamento racional (os reflexos da influência socrática). Dentre os intérpretes criticados estão A. W. Schlegel e Friedrich Nietzsche. Ibid., pp. 120-2.

${ }^{69}$ Veja-se o capítulo: Homer's View of Man. In: Ibid., pp.1-22.
} 
particulares $^{70}$. Já nas Suplicantes de Ésquilo, pela primeira vez na literatura, o personagem toma uma decisão por si só e assume por ela as devidas conseqüências $^{71}$. Há aí o princípio de uma discussão sobre a essência da ação humana, cuja validade é universal! Tornar este princípio público significa recolocar o problema a partir de sua origem: eis a engenhosa contribuição de Snell.

Nesta sua interpretação, as tragédias marcam o exato momento em que se separam definitivamente a realidade e a ficção, os homens e os deuses. Ésquilo, o primeiro a perceber a nova realidade, teria então questionado sobre qual dos caminhos deveriam os homens seguir. A prova disto está em seus enredos: os heróis são colocados frente a uma encruzilhada diante da qual optam conscientemente pela nobre alternativa da morte ${ }^{72}$. A escolha é individual e não sofre, portanto, quaisquer interferências externas. Os deuses permanecem ausentes dela, incompreendidos, e as eventuais alusões a eles nada mais são que o esforço do tragediógrafo em materializar os dilemas morais de sua época, procurando com isso emblemas aptos a suprir o vazio deixado por tal ausência ${ }^{73}$. Como decorrência disto, Ésquilo tornou possível o homem europeu: racional, dotado de um livre-arbítrio e consciente de suas obrigações individuais ${ }^{74}$.

Eurípides, por seu turno, levou adiante estas reflexões iniciadas por Ésquilo. Enquanto este se preocupava com a definição de regras a partir das quais os indivíduos pudessem conviver uns com os outros, aquele abandonou seus personagens à constatação da arbitrariedade da individuação e dos valores

\footnotetext{
${ }^{70}$ No contexto da lírica, "the areas of the will and of the action are not yet opened up". Cf. The Rise of Individual in the Early Greek Lyric. In: Ibid., pp. 43-70. O trecho citado está na página 70 .

71 "For the first time in literature someone toils hard for the sake of responsability and justice, for the purpose of warding off evil". Ibid., p. 102.

${ }^{72}$ Nas palavras de Snell: Ésquilo "tried to uncover, as clearly as he could, the hard core of human action. Under ordinary circumstances, in the confusion of real life, a thousand motifs are intertwined; of the basis form of genuine action, i.e. the free decision, only a pale reflexion rises to the surfice. But tragedy has the power to construct such na archetype of action; it does so by placing a man half way between two claims almost equal in urgency, and having him choose the noble alternative of dead, in full view of the commands of justice and fate". Ibid., pp. 106-7.

${ }^{73}$ Ibid., pp. 108-9.

${ }^{74}$ Para Snell, este homem racional e livre-pensador do Ocidente se opõe tanto ao grego arcaico (do qual Ésquilo não deixa de tomar a forma e os enredos de seus textos), quanto ao oriental. Sobre isso, Ibid., p. 103.
} 
morais, encaminhando-os ao desespero e à loucura. Assim sendo, os dois tragediógrafos estariam unidos na descoberta da vontade individual, cujos dilemas são a garantia de unidade para o gênero trágico.

Com a descrição de tal processo de individualização iniciado com a tragédia, Snell aproxima os dilemas da Atenas de Ésquilo e Eurípides daqueles vividos por Kant e seus contemporâneos. Ao organizar seus argumentos em torno da noção de vontade, também aproxima sua definição de tragédia daquela engendrada por Schiller em fins do século XVIII. A mudança não é aqui de todo desprezível, mas se desenvolve a partir dos mesmos conceitos-chave. Se na definição tradicional a tragédia sugere, ao retratar o embate entre a vontade individual e as forças da natureza, discussões sobre a direção e os limites (morais) das ações humanas, agora esta vontade individual se debate consigo mesma (por meio das representações dos deuses e costumes), produzindo uma similar reflexão moralizante.

$$
* * *
$$

Outro helenista de língua alemã, austríaco, a igualmente influenciar o estudo mais recente da produção esquiliana é Albin Lesky. Se comparado a Snell, ele bem poderia encarnar aqui a imagem mais típica do erudito romântico, preocupado com a atualização de antigas e consagradas discussões sobre a natureza do fenômeno trágico, o qual considera uma concepção de mundo universalmente dada ${ }^{75}$.

Tal interesse sobre o assunto remonta a 1937, ano da publicação de um de seus livros: Die griechische Tragödie $e^{76}$. Lesky intenta aí explicar a especificidade do trágico entre os gregos, tarefa concebível mediante o retorno aos conceitos e preocupações dos poetas/filósofos alemães pós-iluministas, "quando surge uma relação absolutamente nova e fecunda com a tragédia da Antigüidade Grega" 77 . São estas observações sobre o trágico que encaminham o entendimento de Ésquilo.

\footnotetext{
${ }^{75}$ Vê-se revivida a autonomia das idéias estéticas ante as formas. Em um texto de 1937 Lesky já aborda assim o problema. A única versão dele disponível em português é uma reprodução modificada para nova publicação em 1957, mas, a acreditar no prefácio à edição, seu teor mantém-se o mesmo. Cf. LESKY, Albin. Do problema do trágico. In: A tragédia grega.. Trad. J. Guinsburg, A. Guzik, $3^{\mathrm{a}}$ ed., São Paulo: Perspectiba, 1996, pp. 21-55.

${ }^{76}$ Publicada em português como LESKY, Albin. A tragédia grega. op. cit.

${ }^{77}$ Ibid., p. 31. Os gregos, apesar de terem inventado a arte trágica - "uma das maiores façanhas do campo do espírito" (p. 27) - não discorreram sobre a visão de mundo inerente a ela. Coube aos alemães esta tarefa.
} 
Dentre os "antigos mestres", a principal referencia é Goethe. Lesky recupera dele as características ditas necessárias ao bom desenvolvimento da tragédia, quais sejam: um enredo marcado por uma contradição inconciliável e por uma pertinência quanto à vida do espectador, um protagonista capaz de suportar com dignidade sua derrocada, e, por fim, a plena consciência dos personagens acerca de seus destinos ${ }^{78}$. A problemática definida por Goethe, no entanto, não esgota todas as situações conhecidas entre os gregos. Para Lesky é preciso flexibilizá-la ao menos em um ponto, o de uma contradição inconciliável. Se esta característica fosse mantida, apenas um aspecto do trágico se tornaria visível: o conflito trágico, do qual o único possível fim é a destruição. Propõe então englobar aquilo que chama situações trágicas, nas quais as forças em oposição podem encontrar um equilíbrio e salvaguardar o herói (tal como na Orestéia esquiliana).

E quanto à vontade? Também neste ponto Lesky se mostra bastante convencional: tanto no conflito trágico, quanto nas situações trágicas, o elemento central reside no embate entre a vontade humana e os desejos de entidades sobrenaturais (destino, deuses). Em Ésquilo, por exemplo, o trágico se manifesta quando "a ardente vontade do homem topa com uma grande ordem, apoiada no divino, que lhe mostra seus limites e faz com que sua queda se torne significativamente um testemunho desta ordem"79. Vale dizer: aos homens é permitido manifestar vontade própria, mas ainda assim eles precisam adequála a uma outra, mais forte e concomitante à sua (a dos deuses). Este mecanismo é chamado por Lesky de dupla motivação ${ }^{80}$.

A (re)descoberta da dupla motivação, além de confirmar o que já se supunha de longa data, garantiu ao helenista austríaco um sólido reconheci-

\footnotetext{
${ }^{78}$ Ibid., p. 31-8. Schiller e Nietzsche são mencionados neste trecho.

${ }^{79}$ Ibid., p. 104. Em Sófocles a situação é diferente, embora envolva os mesmos elementos básicos: "engenho humano e luta humana, ao lado do inapreensível, inatingível governo dos deuses.", In.: Ibid., p. 148.

${ }^{80} \mathrm{O}$ termo já aparece, referindo-se às ações retratadas nas tragédias esquilianas, em Ibid., p. 107. No entanto, será explorado com mais detalhes em um texto de 1966, Id. Decision and Responsability in the Tragedy of Aeschylus. Journal of Hellenic Studies. Oxford: Alden Press, Vol. 86, 1966, pp. 78-85. Note-se uma transcrição quase que literal da afirmação simultânea de liberdade e necessidade em Schelling e Schiller.
} 
mento por parte dos pares $^{81}$, bem como tornou possível seu afastamento das impressões de Snell quanto à vontade entre os gregos. Nas várias remissões feitas aos trabalhos deste pesquisador até ocorrem concordâncias pontuais entre ambos: Lesky concorda quanto a Ésquilo ser considerado o primeiro a refletir sobre o livre-arbítrio ${ }^{82}$, e também o faz sobre o universal e inestimável valor das obras do poeta; mas a semelhança se encerra aí. Ele não vê na afirmação da vontade o motivo central da tragédia, tampouco sua contribuição ao mundo contemporâneo. Antes, sua leitura dos textos esquilianos apresenta a incapacidade desta vontade em se desenvolver em apartada dos desígnios superiores, sejam eles compreensíveis ou não aos homens ${ }^{83}$. Seu valor está aí, naquilo que evidencia da essência ambígua do homem, em seu eterno conflito consigo mesmo e com o mundo exterior ${ }^{84}$.

Deve-se salientar, porém, que Albin Lesky e Bruno Snell colocaram o problema da vontade como crucial para a compreensão da tragédia esquiliana de um ambiente acadêmico influenciado diretamente pela tradição alemã pósiluminista. Nas primeiras décadas do século XX Goethe e Schiller eram aí tidos como os grandes poetas nacionais, a obra de Nietzsche saía rapidamente do anonimato, os neo-kantianos tinham cada vez mais força acadêmica e a Hermenêutica, tradicionalmente relacionada com o circulo de Jena, conquistava seu espaço. Não era de se estranhar a facilidade e a familiaridade com que estes

\footnotetext{
${ }^{81}$ Quase meio século depois da publicação de suas primeiras obras sobre as tragédia, a perspectiva de Lesky ainda é reconhecidamente "adotada, com diversos matizes, pela maior parte dos helenistas contemporâneos" (VERNANT, Jean-Pierre; VIDAL-NAQUET, Pierre. Mito e tragédia na Grécia antiga I e II. Trad. A. Machado, F. Garcia e M. Cavalcante, São Paulo: Perspectiva, 1999, p. 28); e seus trabalhos considerados de "suma importância" para o estudo das tragédias (KNOX, Bernard. Heroic Temper. Berkeley: University of Califórnia, 1983, p. 37).

${ }^{82}$ Quanto a Ésquilo ser o primeiro a problematizar o ato decisório: "It was Aeschylus who discovered the problem of the uncertainty inherent in every human action" Cf. LESKY, Albin. Decision and Responsability in the Tragedy of Aeschylus, op. cit., p. 80

${ }^{83}$ Nas palavras de Lesky: "in Aeschylus can be clearly shown: the close union of necessity imposed by the gods and the personal decision act. This union leaves a certain space for the will of the individual but at the same time limits it". Ibid., p. 85.

${ }^{84} \mathrm{O}$ valor de Ésquilo é reafirmado em diversas ocasiões, dentre as quais Ibid., p. 85; Id. História da literatura grega. Trad. Manuel Losa, Lisboa: Calouste Gulbenkian, p. 285; Id. A tragédia grega, op. cit., p. 138.
} 
intelectuais reproduziam os termos e, ao menos em parte, as idéias já clássicas sobre o valor e o sentido da arte grega.

Em outros nichos acadêmicos, como é o caso do francês e do inglês, tudo se passou de maneira diferente. Ainda que eles tenham sentido similar impacto das reflexões estéticas alemãs, sua presença ali foi indireta e sujeita à adaptações de outras tradições intelectuais. Vê-se um indício disto quando os trabalhos em língua alemã passam a ser (re)discutidos na Europa do pós-1945: Lesky e Snell são citados com assiduidade, mas os referenciais que lhes deram sustentação, oriundos do século anterior, sequer entram no mérito das críticas e elogios a eles dirigidos ${ }^{85}$.

Importante para o desenvolvimento das discussões posteriores sobre a tragédia, E. R. Dodds é um caso paradigmático nesta direção. Ele demostra conhecer a obra de Snell em 1949, no momento em que profere suas conferências na Berkeley, bem como a importância da discussão em torno do ato decisório entre os gregos. Ainda assim, os conceitos por ele advogados e a base de suas preocupações são bastante distintas das do helenista alemão ${ }^{86}$.

Dodds está mais interessado em promover uma pesquisa, colada à psicanálise, acerca da maneira particular com que os gregos lidaram com o Irracional. Tal ênfase, contrária à forte imagem dos gregos como expressão máxima da racionalidade, deveu muito a influências locais, tais como as de James Frazer e de Gilbert Murray ${ }^{87}$.

No tocante à vontade manifesta nas tragédias esquilianas, Dodds sublinha a importante racionalização sobre o papel das forças espirituais, exteriores aos homens. Já em Homero, nota o helenista, estas forças irracionais servem como justificativa plausível (consciente) para inúmeras atitudes dos heróis. Algo similar tem lugar em Ésquilo - embora no tragediógrafo a lógica da associação

\footnotetext{
${ }^{85}$ Uma exceção deve ser feita a Nietzsche, cuja obra ganha notoriedade quanto à tragédia grega.

${ }^{86}$ Estas conferências foram publicadas em 1950. A versão utilizada no presente trabalho é a seguinte: DODDS, E. R. The Greeks and the Irrational. Berkeley: University of California, 1984

${ }^{87}$ Dodds dedica o trabalho a Murray e cita elogiosamente Frazer em seu prefácio. Sobre o significado destes dois nomes para os estudos clássicos ingleses, cf. ACKERMAN, R. The Myth and Ritual School. Londres: Routledeg, 2002. Importante também mencionar aqui um trabalho Murray sobre Ésquilo. Citado por Dodds, ele traz um título bastante significativo. MURRAY, Gilbert. Aeshylus, the creator of Tragedy. Oxford: Clarendon, 1940.
} 
entre o sobrenatural e as atitudes humanas passe a ser orientada por dilemas de ordem moral ${ }^{88}$. Desta maneira, desde sua história mais remota, os gregos entendiam a ação como tendo uma dupla proveniência. De um lado, há o agente imediato (quem é possuído). De outro, a força possuidora. É esta quem incide sobre aquele e determina verdadeiramente a direção de seus atos, ainda que ambos tenham de suportar os desdobramentos do evento. Dodds denomina este fenômeno over-determination (doravante, sobre-determinação) ${ }^{89}$.

$$
* * *
$$

Se a análise das opiniões acerca da tragédia esquiliana se restringisse apenas aos trabalhos destes pesquisadores, publicados até o final da década de 40, o campo de discussões seria, no mínimo, algo controverso. Sobre as mesmas fontes três diferentes interpretações foram emitidas, todas gravitando em torno da noção de vontade: ou a vontade individual se realiza plenamente (Snell), ou ela o faz em paralelo à afirmação de uma vontade superior e exterior ao homem (dupla motivação de Lesky), ou ainda é caracterizada como algo determinado externamente (sobre-determinação de Dodds). Mas a polêmica não se encerra por aqui.

A situação constrangedora de uma ciência incapaz de produzir o consenso foi ainda agravada nos anos seguintes, quando vieram a público duas diferentes traduções do Agamêmnon de Ésquilo. Na primeira delas, de 1950, Eduard Fraenkel sustenta a imagem cavalheiresca de Agamêmnon. Ele, o protagonista do enredo trágico, seria um distinto aristocrata, amado por seu povo e incapaz de cometer qualquer erronia por livre e espontânea vontade. Sua derrocada final foi fruto de um golpe do destino, isentando o monarca de qualquer responsabilidade $^{90}$. Sete anos depois, D. L. Page publica uma impressão oposta no prefácio de sua tradução: Agamêmnon é um tirano e acaba construindo para

\footnotetext{
${ }^{88} \mathrm{Ou}$ seja, estas forças se manifestam em decorrência da culpa ou inocência do personagem. Isto ocorre porque, segundo Dodds, Ésquilo representa um momento distinto de Homero na cultura grega, o da guilt-culture (por oposição ao da shame-culture). Sobre isso, cf. DODDS, E. R. The Greeks and the Irrational, op. cit., pp. 28-63.

${ }^{89} \mathrm{O}$ termo é usual em Dodds; Ibid., p. 6, 16, 30-51. Em um artigo posterior (1960), dedicado aos dilemas políticos e morais da Orestéia, a idéia de sobre-determinação terá sua validade reforçada. Veja-se uma versão deste artigo em Id. The Ancient Concept of Progress. Oxford: Clarendon, 1973, pp. 45-63.

${ }^{90}$ FRAENKEL, E. Aeschylus, Agamemnon. 2 volumes, Oxford: Clarendon, 1950.
} 
si um desfecho fatal, marcado pelo ódio dos deuses e dos mortais quanto à sua torpe ambição ${ }^{91}$.

Aqui, a eventual culpa do monarca ganha uma preponderância na discussão, embora isto em nada afaste o dilema da livre-escolha. A sentença teria sido justa, afinal, se os crimes perpetrados por Agamêmnon contra sua família e Tróia fossem obras de seu arbítrio. Injustas, por outro lado, se oriundas de algum motivo exterior: ou poderia ser ele julgado por uma fatalidade?

$$
* * *
$$

A década de 1960 foi marcada por este dilema quanto às tragédias de Ésquilo. Vários helenistas já consagrados se apressaram em dar seu parecer sobre o tema. Foram mencionados anteriormente os textos em que Dodds e Lesky reafirmam suas opiniões nestes mesmos anos ${ }^{92}$. Também a argüição de Snell garante seu espaço com o endosso dado à sua tese pela psicologia histórica de Barbu $^{93}$. Mas não só os antigos mandarins que participam do debate.

Hugh Lloyd-Jones, atuante em Oxford desde os anos 1950, aproveita o ensejo para desvelar os desígnios divinos no Agamêmnon $^{94}$. Por trás de todas as ações dos personagens ele vê se manifestar algo inevitável, um destino previamente determinado por Zeus. Assim, o rei dos deuses fez do chefe da expedição a Tróia seu instrumento punitivo aos atentados troianos quanto às leis de hospitalidade (Zeus, para efetuar seus planos, chega a constranger Agamêmnon a matar a própria filha). Uma vez findo o conflito é a vez do monarca de Argos suportar a dupla maldição imposta por Zeus: aquela que pesa sobre sua família (a qual remete ao banquete de Tieste) e sobre a de Clitemnestra.

Em 1965, outro texto aparece para alimentar a controversa discussão ${ }^{95}$. N. Hammond, professor de Bristol, sugere um Ésquilo sensível tanto à liber-

\footnotetext{
${ }^{91}$ PAGE, D. L. e DENNISTON, J. D. Aeschylus, Agamemnon. Oxford: Clarendon, 1957. ${ }^{92}$ Veja-se notas 80 e 89.

${ }^{93}$ BARBU, Z. Problems of Historical Psychology. Londres: s.e., 1960.

${ }^{94}$ LLOYD-JONES, Hugh. The Guilt of Agamemnon. Classical Quartely, XII, 2, 1962, pp. 187-199. No início deste texto o autor cita a polêmica das duas traduções (Fraenkel e Page), bem como um artigo de Dodds já mencionado (nota 89). Em um texto anterior o autor já havia sugerido similar leitura de Zeus. Cf. Id. Zeus in Aeschylus. Journal of Hellenic Studies, Oxford: Alden Press, Vol. 76, 1956, pp. 55-74.

${ }^{95}$ HAMMOND, N G. I. Personal Freedom and Its Limitations in the Oresteia. Journal of Hellenic Studies. Oxford: Alden Press, Vol. 85, 1965p, p. 42-55. No decorrer de seu texto são citados Goethe (p. 55), Lloyd-Jones (p.42, 45-7, 53), Dodds (p.43, 50), Page (4546, 48-49), e Fraenkel (43, 45, 47-49, 51-52)
} 
dade humana, quanto à seus limites. Cada ação seria possível apenas dentro de um leque de escolhas previamente dado - o quinhão de cada um, sua relação com os destinos alheios. A noção grega de Moira ganha aí especial destaque. Cabe a ela, segundo Hammond, ligar os destinos dos membros de uma comunidade e o corpo e a alma de um indivíduo. Um trecho de seu artigo deixa bem evidente a associação: "a conclusão geral à qual nós chegamos é que Ésquilo acredita seres os homens livres para tomarem algumas decisões e que ao mesmo tempo ele reconhece as limitações impostas aos homens por suas 'moiras' ou quinhão, em termos tanto de identidade, quanto de circunstância"'96.

Já Andre Rivier, em 1968, pôs em questão termos como vontade e livrearbítrio $^{97}$. Conhecedor da recente bibliografia sobre o tema, ele cita todos os trabalhos acadêmicos até aqui mencionados, apontando como teriam eles se tornado reféns das categorias utilizadas em suas respectivas análises. Para ele, os personagens de Ésquilo não agem porque querem, tampouco porque alguma Vontade superior se impôs. Antes, suas ações refletem a consciência de uma necessidade prenhe de reverência sagrada. Vale dizer: a religiosidade característica dos gregos é a garantia de um nexo lógico para suas ações ${ }^{98}$. Ainda assim, poder-se-ia questionar, até que ponto a substituição da idéia de vontade por necessidade leva adiante o entendimento do sentido original das tragédias esquilianas? Schiller e Schelling não se valiam também deste termo?

Cinco anos depois da publicação do texto de Rivier, Jean-Pierre Vernant reforça o desconforto com a utilização do conceito vontade ${ }^{99}$. Sua análise fundamenta-se na denuncia, semelhante à de Rivier, da inexistência de uma tal noção entre os contemporâneos de Ésquilo. Assim, sugere ele, uma explicação científica da tragédia deveria seguir outro curso, qual seja, procurar discernir

\footnotetext{
${ }^{96}$ No original: "The general conclusion to which we have come is that Aeschylus believed men to be free in making some decisions and that at the same time he recognised the limitations imposed upon men by their 'moira' or portion, in terms both of identity and circunstance". Ibid., p. 53 (a tradução é nossa).

${ }^{97}$ RIVIER, A. Remarques sur le "Nécessaire" et la "Nécessité" chez Eschyle. op. cit. ${ }^{98}$ Ibid., p. 38.

${ }^{99}$ VERNANT, J.-P. Esboços da vontade na tragédia grega. In: VERNANT, J.-P. e VIDALNAQUET, P. Mito e tragédia na Grécia antiga I e II. op. cit., p. 25-52.
} 
e compreender as categorias nativas utilizadas para designar a ação e o agente, bem como seus desdobramentos psico-sociais.

A análise dos pressupostos éticos de Aristóteles instrumentalizam o helenista francês em seu raciocínio. Aqui, não é o livre-arbítrio individual que orienta a escolha, mas as disposições internas do caráter, a prática de vícios e virtudes. Por detrás do homem sempre aparecem agindo estas forças maiores que ele, comandando seus atos e impedindo seu total discernimento quanto aos sentidos a eles agregados. Em outras palavras, o agente não aparece como matriz da ação, pois ela não se dá em um tempo, em uma seqüência inteligível de atos. Agir, para Vernant, deve ser associado ao imiscuir-se do tempo, a um despojamento interior do agente; e a obra, tomada como efeito da ação, revelase assim maior que seu próprio realizador. O período de transição em que se encontra o direito ático corrobora tais fatos: se há nele a idéia da culpabilidade, há também pouca clareza quanto à intencionalidade do criminoso.

Sobre a aplicabilidade deste raciocínio aos textos de Ésquilo, Vernant diz:

Êtos, o caráter, daímon, a potência divina, eis, portanto, as duas ordens de realidade onde se enraíza em Ésquilo a decisão trágica. Situando-se a origem da ação, ao mesmo tempo, no homem e fora dele, a mesma personagem aparece ora como agente, causa e fonte de seus atos, ora como alguém que é movido, que está imerso numa força que o ultrapassa e o $\operatorname{arrasta}^{100}$.

Esboço da vontade. Origem externa e interna. Potência divina e caráter humano. Daímon e êtos. Se a especificidade da explicação de Vernant fosse calcada nestes termos, ela bem poderia ser confundida com a de qualquer outro dos helenistas já citados.

Para além disto, o que acrescenta algo à perspectiva vernantiana (e lhe dá ares de consenso) é a relação entre a tragédia esquiliana e o seu contexto. A explicação via contexto não tem nada de revolucionário se aplicada à tragédia. De uma forma ou de outra, todos as interpretações produzidas no século XX situaram estes textos ante os parcos dados disponíveis sobre a época que os concebeu. Assim, eventos relatados nos enredos trágicos foram comumente associados a fatos tidos como reais; termos aí presentes, explicados a partir

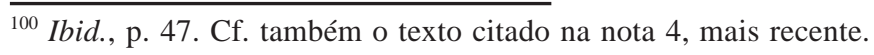


das instituições sociais das quais elas supostamente se originaram. Vernant, porém, inovou ao mesclar sua análise do contexto às críticas proferidas contra o humanismo vigente nos estudos clássicos da época, bem como à fuga dos temas pontuas ${ }^{101}$. Ao melhor estilo estruturalista, em vigor nos anos 1960-70, definiu primeiro a Pólis para depois entrar nos seus pormenores.

Mas como se pode entender essa sua descoberta? Desde As Origens do Pensamento Grego (1962) Vernant a apresenta como um momento específico da história grega ${ }^{102}$. Nesta trajetória, o helenista vê um primeiro momento, micênico, em que as atribuições políticas eram concentradas na mão de um só indivíduo (tal como um monarca absoluto). Na seqüência, com as sucessivas invasões ocorridas na península balcânica, os reis vão perdendo espaço para confrarias de guerreiros, os quais repartem entre si os poderes outrora concentrados. Por fim, em respostas aos conflitos sociais daí provenientes, as atribuições passam a ser sucessivamente divididas, abarcando um número cada vez mais significativo de membros da comunidade. Eis um processo de individualização, de autonomização das várias esferas da vida social. São indícios disto a nova formação hoplítica, na qual os cidadãos se protegem mutuamente; a secularização do uso da palavra, produzindo novos mestres da verdade; e o afrouxamento dos laços de parentesco ${ }^{103}$.

A mudança daí proveniente atende por um nome: a invenção do político. A evolução do direito ático, a difusão do voto individualizado para cada cidadão, a rotina das assembléias, as tragédias gregas; todos estes dados apontam para um espaço público primordial. É ele que impõe a percepção da ruptura ao homem grego, uma ruptura entre um passado mítico e um presente racional (uma racionalidade própria dos gregos, por certo). É ele que transforma as tragédias em entretenimento, ficção, dando ocasião ao homem da Pólis visualizar a si mesmo nelas ${ }^{104}$.

\footnotetext{
${ }^{101}$ Sobre a ruptura de Vernant e as hermenêuticas em voga na Europa (com especial destaque à França), cf., GUIMARÃES, José. A querela dos humanistas. Humanas. Porto Alegre: UFRGS, v. 23, n. 1/2, 2000, pp. 145-178.

${ }^{102}$ VERNANT, J.-P. As origens do pensamento grego. Trad. Isis Fonseca, $9^{\mathrm{a}}$ ed., Rio de Janeiro: Bertrand, 1996.

${ }^{103}$ Uma análise mais detalhada de tal processo pode ser encontrada na primeira parte de nosso artigo: BENTHIEN, Rafael Faraco. Razão e mito: Vernant em questão. Revista Vernáculo. Curitiba: s.e., 1, 2000, pp. 9-13.

${ }^{104}$ VERNANT, J.-P. e VIDAL-NAQUET, P. Mito e tragédia na Grécia antiga I e II, op. cit., pp. 1-24.
} 
Há ainda um outro ponto favorável a Vernant. Suas análises confirmam a pertinência da vida do homem grego para o ocidental. Este, afinal, foi inventado por aquele. Daí a necessidade e a autoridade de um tal estudo: a Pólis revela algo sobre o homem ocidental! A tragédia, parte integrante desta noção, também o faz. Não por acaso a vontade se apresenta nela como um esboço. Isto ocorre porque a realização da vontade na tragédia está para sua manifestação atual como a política antiga está para a contemporânea. Uma indica a outra, é sua precursora.

\section{0 triunfo da vontade}

Embora o vínculo entre a política e a tragédia tenha logrado sucesso na academia, como indiciam as constantes remissões e re-leituras das quais ele é objeto privilegiado $^{105}$, a polêmica em torno da vontade permanece aberta e serve de alerta aos classicistas. Ela deixa ao menos duas perguntas no ar: 1) até que ponto, passados mais de dois séculos, as impressões de Schiller acerca das tragédia gregas não foram naturalizadas, tornando os leitores destas reféns dos possíveis desdobramentos daquelas? 2) até que ponto há no tempo presente, entre os classicistas, uma discussão criteriosa sobre o objetivo de suas análises e o método nelas empregado?

Quanto às tragédias esquilianas, não apareceram muitos novos indícios para enriquecer o debate. Continua-se sabendo muito pouco quanto a seu produtor, as idéias que professava diariamente, os espaços sociais que freqüentava, seus amigos e adversários. Pode-se dizer o mesmo da recepção de seus textos: embora seja possível dizer que alguns deles foram declarados vitoriosos, os juizes que o fizeram continuam sendo uma incógnita, bem como os seus critérios de sua escolha e se esta teve, ou não, aval da maioria do público.

Diante de tão poucas informações, são igualmente escassos os caminhos abertos ao pesquisador. Por um lado, pode-se imaginar em Ésquilo as semelhança que se bem entender. Surge assim um rico mosaico de imagens sedimentadas uma sobre a outra: o Ésquilo inventor do livre-arbítrio, o conhecedor dos desígnios divinos, o artista político. Por outro lado, pode-se começar a pesquisa com a constatação mesma dos limites dessa criatividade.

${ }^{105}$ Cf. ROMILlY, Jacqueline de. La Tragédie Grecque. Paris: PUF, 1982; SEGAL, Charles. O ouvinte e o espectador. In: VERNANT, J.-P. (org.) O homem grego. Trad. M. Figueiredo, Lisboa: Presença, 1994. pp. 173-197; LORAUX, Nicole. Maneiras trágicas de matar uma mulher. Trad. Mário da Gama Kury, Rio de Janeiro: Zahar, 1988; ZAK, William. The Polis and the Divine Order. Londres: Associated University Press, 1995. 


\section{Referências Bibliográficas}

ARENTD, Hannah. Entre o Passado e o Futuro. Trad. M. Barbosa, São Paulo: Perspectiva, 1972.

ACKERMAN, R. The Myth and Ritual School. Londres: Routledeg, 2002.

BARBU, Z. Problems of Historical Psychology. Londres: s.e., 1960.

BEAUMARCHAIS, P. de. As bodas de Fígaro. Trad. B. Heliodora, São Paulo: Edusp, 2001.

BENJAMIN, W. O conceito de crítica de arte no romantismo alemão. $2^{\circledR}$ ed., São Paulo: Iluminuras, 1999.

BENTHIEN, Rafael Faraco. Lessing e Schiller: duas idéias acerca da tragédia. In: Anais do X evento de iniciação científica. Curitiba: UFPR, 2002. p. 373. Razão e Mito. Revista Vernáculo. Curitiba: s.e., 1, 2000. pp. 8-18. BOURDIEU, Pierre. As regras da arte. Trad. M. L. Machado, São Paulo: Cia das Letras, 1996.

Economia das trocas lingüísticas. Trad. Sergio Miceli, São Paulo: Edusp, 1998.

DETIENNE, Marcel. Comparer l'incomparable. Paris: Seuil, 2000.

DOODS, E. R. The Greeks and The Irrational. Berkeley: University of California, 1984. The Ancient Concept of Progress. Oxford: Clarendon, 1973.

DUMONT, Louis. O individualismo. Trad. Álvaro Cabral, Rio de Janeiro: Rocco, 2000.

ELIAS, Norbert. Mozart, sociologia de um gênio. Trad. M. Shröter, Rio de Janeiro: Zahar, 1995.

La Sociedad Cortesana. Trad. Guillermo Hirata, México D. F.: Fondo de Cultura Economica, 1996.

HAMMOND, H. G. I. Personal Freedom and Its Limitations in the Oresteia. JHS. Oxford: Alden Press, 1965, pp. 42-55.

FRAENKEL, E. Aeschylus, Agamemnon. (2 Vol.) Oxford : Clarendon, 1950.

GOGH, Vincent van. Cartas a Théo. Trad. Pierre Ruprecht, Porto Alegre: L\&PM, 1999.

GUIMARÃES, José. A querela dos humanistas. Humanas. Porto Alegre: UFRGS, v. 23, n. $1 / 2,2000$, pp. $145-178$.

KANT, Immanuel. A crítica da razão pura. Trad. Manuela Pinto dos Santos e Alexandre Fradique Morujão, $4^{a}$ ed., Lisboa: Calouste Gulbenkian, 1997. 
. Crítica da razão prática. Trad. Artur Morão, Lisboa: Edições 70. Crítica da faculdade do juízo. Trad. Valério Rohden e António Marques, $2^{\mathrm{a}}$ ed., Rio de Janeiro: Forense Universitária, 2002.

KNOX, Bernard. Heroic Temper. Berkeley: University of Califórnia, 1983.

LESKY, Albin. A tragédia grega. Trad. Jacó Guinsburg, Geraldo Gerson de Souza e Alberto Guzik, $3^{a}$ ed., São Paulo: Perspectiba, 1996.

História da literatura grega. Trad. Manuel Losa, Lisboa: Calouste Gulbenkian, 1995.

Decision and Responsability in the Tragedy of Aeschylus. JHS. Oxford: Alden Press, Vol. 86, 1966, pp. 78-65.

LESSING, Gotthold. E. Laocoonte. Trad. Márcio Seligmann-Silva, São Paulo: Iluminuras, 1998.

LLOYD-JONES, Hugh. Zeus in Aeschylus. JHS, Oxford: Alden Press, Vol. 76, 1956, pp. 55-74

The Guilt of Agamemnon. The Classical Quartely. XII, 2, 1962, pp. 187-199.

LORAUX, Nicole. Maneiras trágicas de matar uma mulher. Trad. Mário da Gama Kury, Rio de Janeiro: Zahar, 1988.

MOST, Glenn. Da tragédia ao trágico. Filosofia Política. Rio de Janeiro: Zahar, série III, n. 1, 2001, pp. 20-35.

NIETZSCHE, Friedrich. O nascimento da tragédia. Trad. Jacó Guinsburg, $2^{\mathrm{a}}$ ed., São Paulo: Cia das Letras, 1999.

NOVALIS, Friedrich von H. Pólen. Trad. Rubens Filho, $2^{\mathrm{a}}$ ed., São Paulo: Iluminuras, 2001.

PAGE, D. L.; DENNISTON, J. D. Aeschylus, Agamemnonn. Oxford: Clarendon, 1957. PAINE, Thomas. Rights of Man. Nova York: Prometheus, 1987.

RIVIER, Andre. Remarques sur le "Nécessaire" et la "Nécessité" chez Eschyle. Revue des Études Grecques. n. 384-385, jan.-junho 1968, pp. 5-39.

ROMILLY, Jacqueline de. La Tragédie Grecque. Paris: PUF, 1982. ; VERNANT, Jean-Pierre (orgs.) Pour L'amour du Grec. Paris: Bayard, 1999.

SCHELLING, F. Filosofia da arte. Trad. Márcio Suzuki, São Paulo: Edusp, 2001. 
SCHILLER, Friedrich. Teoria da tragédia. Trad. Anatol Rosenfeld, São Paulo: Herder, 1964.

A educação estética do homem. Trad. Roberto Schwarz e Márcio Suzuki, $3^{a}$ ed., São Paulo: Iluminuras, 1995.

SCHLEGEL, F. Dialeto dos fragmentos. Trad. Márcio Suzuki, São Paulo: Iluminuras, 1997.

SEGAL, Charles. O ouvinte e o espectador. In: VERNANT, Jean-Pierre (org.) $O$ homem grego. Lisboa: Editorial Presença, 1994. pp. 173-197.

SNELL, Bruno. The Discovery of the Mind. Trad. T. G. Rosenmeyer, Nova York: Dover, 1982.

VERNANT, J.-P. As origens do pensamento grego. Trad. Isis Fonseca, $9^{\mathrm{a}}$ ed., Rio de Janeiro: Bertrand, 1996.

. Entre mito e política. Trad. Cristina Muraccho, São Paulo: Edusp, 2002. ; VIDAL-NAQUET. Mito e tragédia na Grécia antiga I e II. Trad.

A. Machado, F. Garcia e M. Cavalcante, São Paulo: Perspectiva, 1999.

WISNIK, José Miguel. O som e o sentido. $2^{2}$ ed., São Paulo: Cia das Letras, 2000.

ZAK, William F. The Polis and the Divine Order. Londres: Associated University Press, 1995. 